\title{
Mitral cell development in the olfactory bulb of sharks: evidences of a conserved pattern of glutamatergic neurogenesis
}

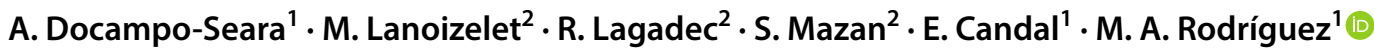

Received: 28 December 2018 / Accepted: 7 June 2019 / Published online: 15 June 2019

(c) The Author(s) 2019

\begin{abstract}
In mammals, the development of the olfactory bulb $(\mathrm{OB})$ relies in part on the expression of transcription factors involved in the specifications/differentiation of glutamatergic cells. In a previous study from our group, a high molecular similarity was reported between mammals and cartilaginous fishes regarding the neurogenic mechanisms underlying the development of glutamatergic cells in the telencephalon. However, information about the transcriptional program operating in the development of the glutamatergic system (mainly represented by mitral cells) in the OB is lacking in the catshark Scyliorhinus canicula, a cartilaginous fish. Using immunohistochemistry and in situ hybridization techniques, we have found that, previously to the appearance of the olfactory primordium (OP), proliferating cells expressing Pax6 with molecular hallmarks of progenitor radial glia were located in the ventrolateral pallial ventricular zone. Later in development, when the OP is recognizable, a stream of Pax6-positive cells were observed between the ventricular zone and the OP, where transcription factors involved in mitral cell development in mammals (ScTbr2, ScNeuroD, Tbr1) are expressed. Later in development, these transcription factors became expressed in a layered-like structure where ScVglut1, a marker of mitral cells, is also present. Our data suggest that the transcriptional program related with the specification/differentiation of glutamatergic cells in the telencephalon has been conserved throughout the evolution of vertebrates. These results, in combination with previous studies concerning GABAergic neurogenesis in sharks, have evidenced that the OB of mammals and sharks shares similarities in the timing and molecular programs of development.
\end{abstract}

Keywords Olfactory bulb $\cdot$ Catshark $\cdot$ Mitral cells $\cdot$ Development $\cdot$ Glutamatergic lineage $\cdot$ Pax6

\section{Introduction}

The sense of smell is essential for a variety of behaviors in vertebrates like mating, feeding, fear and aggression. The organization of the olfactory system is well conserved in vertebrates not only in terms of function, but also in connectivity and also concerning the developmental origin of

E. Candal and M. A. Rodríguez have equally contributed to this work.

\section{A. Rodríguez \\ miguelangel.rodriguez.diaz@usc.es}

1 Departamento de Bioloxía Funcional, Centro de Investigación en Bioloxía (CIBUS), Universidade de Santiago de Compostela, 15782 Santiago de Compostela, Spain

2 CNRS, Sorbonne Universités, UPMC Univ Paris 06, UMR7232, Observatoire Océanologique, Banyuls sur Mer, France different structures within the peripheral and central olfactory system. Numerous investigations in mammals indicate that the olfactory system constitutes an excellent model to study various developmental aspects of the nervous system such as neurogenesis, neuronal migration, and axon guidance (Blanchart et al. 2011; Díaz-Guerra et al. 2013; Lim and Alvarez-Buylla 2016).

In rodents, the main olfactory system is related with the olfactory chemoreception of odorants and comprises a primary olfactory pathway consisting of the nasal olfactory epithelium (OE) and the main olfactory bulb (MOB), and a secondary olfactory pathway that includes all cortical regions directly innervated by MOB projection neurons (known together as the olfactory cortex); the olfactory cortex in turn releases signals to higher cortical areas involved in conscious perception and to limbic areas that control basic drives and emotions (reviewed in Boehm 2006; Treloar et al. 2010). 
Besides, olfactory chemoreception of pheromones depends on an accessory olfactory system called vomeronasal system (VNS) that comprises the neuroepithelium of the vomeronasal organ (VNO or Jacobson's organ) and the accessory olfactory bulb (AOB); signals from the AOB are relayed to regions of the amygdala and hypothalamus implicated in behavioral and physiological effects of pheromones (for review see Boehm 2006; Huilgol and Tole 2016).

In rodents, projecting axons of the olfactory receptor neurons located in the OE reach the telencephalic vesicle and induce the growth of the olfactory bulb primordium (OP). The MOB becomes evident macroscopically around the day 12 of embryonic development (E12; Gong and Shipley 1995). During the morphogenesis of the mouse MOB, projection neurons (mitral cells) are born from pallial progenitor cells and, then, interneurons (granule and periglomerular cells) that arise from the subpallium migrate tangentially toward their destination within the MOB (Blanchart et al. 2006; Vergaño-Vera et al. 2006; Imamura and Greer 2013; Huilgol and Tole 2016). The cellular organization of the $\mathrm{MOB}$ and $\mathrm{AOB}$ is similar. Projection neurons of the MOB and anterior $\mathrm{AOB}$ arise from the same region; however, differences in the domains of origin and migration routes of projection neurons are present between the anterior and posterior regions of the AOB. Interneurons of the MOB and $\mathrm{AOB}$ are born in the same region (for review see: Huilgol et al. 2013; Huilgol and Tole 2016).

Despite most studies about the olfactory system are focused on mammals, other animal models are necessary nowadays to understand different embryological aspects occurring during development of the olfactory system. Cartilaginous fishes represent one of the three living lineages of vertebrates (cyclostomes, cartilaginous fishes and bony vertebrates). Cartilaginous fishes diverged from bony vertebrates about 450 million years ago. Embryological studies in cartilaginous fishes reveal a conserved pattern of gene expression in diverse developmental process across gnathostome vertebrates (Gillis and Shubin 2009), and also morphogenetic processes and regionalization patterns are strikingly similar to mammals (Rodríguez-Moldes et al. 2017). More recently, the whole-genome analysis of three elasmobranch species has shown the presence of genes related with homeostasis, reproduction, and mechanisms for the generation of neuronal cell diversity homologous to that found in mammals (Hara et al. 2018). These studies indicate that cartilaginous fishes represent a key model for better knowledge of evolution of gnathostome brain development.

Moreover, cartilaginous fishes possess a well-developed sense of smell that is important for survival, localizing preys, avoiding predators, and chemosensory communication (for review see: Yopak et al. 2015). Numerous investigations have been referred to the adult olfactory system in elasmobranchs fishes. Several studies have been referred to the cell organization of the OE of the catshark, where sensory ciliated neurons, which in tetrapod vertebrates project to the MOB, are lacking; however, in the $\mathrm{OE}$, microvillous olfactory receptor neurons and crypt sensory neurons are clearly recognizable (Theisen et al. 1986; Ferrando et al. 2006a, b, 2009, 2010, 2012; Zaccone et al. 2011). In addition, genomic studies show that the predominant olfactory receptor type in the catshark and the elephant shark is the vomeronasal type2 receptor (V2R) (Sharma et al. 2019). These evidences together with ultrastructural and immunohistochemical data indicate that in the catshark the olfaction could mainly rely on a VNS (Ferrando and Gallus 2013). Interestingly, anatomical and molecular data show a primordial accessory olfactory system in the sea lamprey (Chang et al. 2013) and an accessory olfactory system was also identified in the African lungfish (González et al. 2010) and zebrafish (Biechl et al. 2017).

Though the OBs are laminated structures, in sharks, they do not present the six cell layers described in mammals. The cytoarchitectonic organization of the $\mathrm{OB}$ in the catshark has been investigated by classic staining techniques and summarized by Smeets et al. (1983). Three main layers can be observed in this species: the olfactory nerve layer, the glomerular layer and the granular layer. Two main types of cells have been described in the OB: interneurons and projection neurons. The ultrastructure of the OB (Dryer and Graziadei 1996) and the arrangement of the primary and secondary olfactory projections have been described in different elasmobranchs species (Dryer and Graziadei 1993, 1994; Yáñez et al. 2011). Besides, in juveniles and/or adults of $S$. canicula, the OB have been characterized using antibodies against enzymes like tyrosine hydroxylase (TH) (Carrera et al. 2012), glutamate acid decarboxylase (GAD) (Sueiro 2003), neuronal nitric oxide synthase (nNOS) (Ferrando et al. 2012) and choline acetyltransferase (ChAT) (Anadón et al. 2000); other neuroactive substances such as glycine (Anadón et al. 2013), serotonin (Carrera et al. 2008a) and diverse neuropeptides (Rodríguez-Moldes et al. 1993; Molist et al. 1995; Teijido et al. 2002) have also been detected in the $\mathrm{OB}$ of the catshark.

In contrast, studies about development of the olfactory system are scarce and mainly focused on the peripheral olfactory system (Ferrando et al. 2012; Ferreiro-Galve et al. 2012; Quintana-Urzainqui et al. 2014). Using tract-tracing and immunohistochemical techniques, the development of the peripheral olfactory system of the catshark Scyliorhinus canicula has been described, and numerous Pax6-expressing cells have been observed in the OE, and along the developing olfactory nerve (Ferreiro-Galve et al. 2012; QuintanaUrzainqui et al. 2014). In addition, numerous Pax6-positive cells have been also reported in the ventricular zone of the ventrolateral pallium of embryos before the appearance of the OP (Ferreiro-Galve et al. 2012). However, the phenotype 
of these cells is unknown and their relationship with OB development has not been addressed so far. On the other hand, information about the origin, specification and differentiation of the OB cell types in the catshark is scarce and restricted to dopaminergic cells. These cells originate in a subpallial ventricular domain in late embryos and reach the OB following a route named lateral stream. The presence of TH-ir cells in this stream, as well as in the OB of stage 32 embryos, indicate that these cells may be the source of the granular and periglomerular cells of the mature $\mathrm{OB}$ (Ferreiro-Galve et al. 2012; Carrera et al. 2012; QuintanaUrzainqui et al. 2015). However, information about the development of OB glutamatergic cells (mitral cells) is lacking in sharks.

The transcriptional program involved in the specification and differentiation of mitral cells is well known in mammals and, curiously, is the same that operates on the specification/ differentiation of pallial glutamatergic neurons before the mature organization of the OB is achieved (for review see: Bulfone et al. 1998; Englund et al. 2005; Díaz-Guerra et al. 2013; Imamura and Greer 2013; Kahoud et al. 2014; Roybon et al. 2015; Mihalas and Hevner 2017). Different experimental approaches carried out in mammals have shown that the transcription factor-paired homeobox 6 (Pax6), together with Sox 2 (a transcription factor expressed in stem cells), is involved in neural stem cell self-renewal, neurogenesis and differentiation of specific neural cell types (Dellovade et al. 1998; Nomura and Osumi 2004; Kohwi et al. 2005; Sansom et al. 2009; Gómez-López et al. 2011; Curto et al. 2014). Pax6-expressing cells have been reported in the ventricular zone of the embryonic pallium as well as in the developing OB in mammals (Stoykova and Gruss 1994; Puelles et al. 2000), amphibians (Franco et al. 2001) and elasmobranch fishes, even though in the catshark, Pax6 is expressed throughout the $\mathrm{VZ}$ of the pallium, as in other vertebrates, the gradient described in mammals (lateral high, medial low and anterior high, and posterior low) is not evident in sharks (Ferreiro-Galve et al. 2012; Quintana-Urzainqui et al. 2012; Rodríguez-Moldes et al. 2017). In the MOB of rodents, projection neurons (mitral and tufted cells) derive from Pax6-positive radial glia progenitors located in the ventricular zone of the dorsal pallium (Winpenny et al. 2011; Imamura et al. 2011; Imamura and Greer 2013). Besides, Pax6 regulates the expression of two T-box genes (Tbr1 and Tbr2, the latter also known as Eomes) (Bulfone et al. 1995; Méndez-Gómez et al. 2011; Mizuguchi et al. 2012; Imamura and Greer 2013), which are also expressed along mitral cell development in the OB in rodents (Bulfone et al. 1999; Faedo et al. 2002; Winpenny et al. 2011; Mizuguchi et al. 2012; Roybon et al. 2015), birds (Bulfone et al. 1999), amphibians (Moreno et al. 2003; Brox et al. 2004) and zebrafish (Mione et al. 2001; Mueller and Wulliman 2016). In addition, the basic helix-loop-helix transcription factor
NeuroD is also implicated in the terminal differentiation of mitral cells (Boutin et al. 2010; Osorio et al. 2010; Roybon et al. 2015). At the end of the embryonic period in mammals, mitral cells begin to express the glutamate vesicular transporter 1 (Vglut1; Ohmomo et al. 2011), which is also a marker of mitral cells in other groups of vertebrates such as reptiles (Sarkar and Atoji 2018). Mutant mice, where expression of Pax6, Tbr1 and Tbr2 is altered, show a disrupted OB morphogenesis indicating that this transcriptional cascade plays a key role in the correct morphogenesis of the OB (Bulfone et al. 1998; Nomura and Osumi 2004; Kahoud et al. 2014). Curiously, in mammals Tbr1 is also implicated in the specification of the anterior $\mathrm{AOB}$; however, the specification of the posterior $\mathrm{AOB}$ is under the control of different genes (for review see: Huilgol and Tole 2016).

With the purpose of shedding light into the development of the central olfactory system in an evo-devo context, we have characterized Pax6 immunoreactive cells present in the ventricular zone of the ventrolateral pallium embryos of catshark with different progenitor markers such as Sox2 (stem cells), GFAP and BLBP (radial glia cells) and PCNA (proliferating cells). Then, we have studied the expression pattern of Pax6, once the OP emerges, and we have analyzed the expression pattern of transcription factors (such as Tbr2, NeuroD and Tbr1) and the vesicular transporter of glutamate 1 (vGlut1) related to differentiation of glutamatergic cells in the developing OB using immunocytochemistry and in situ hybridization techniques. In addition, we have carried out a BrdU pulse-chase study to determine the developmental period where these cells are generated. Finally, we have discussed our results in an evo-devo context and also at the light of the possibility of the existence of an AOB in the catshark.

\section{Materials and methods}

\section{Experimental animals}

In the present study, we have analyzed 15 embryos of $S$. canicula from stages 30 (S30) to 32 (S32) of development. Embryos were provided by the Marine Biological Model Supply Service of the CNRS UPMC Roscoff Biological Station (France) and the Oceanographic Observatory of Banyuls sur Mer (France). Embryos were staged by their external features according to Ballard et al. (1993). Sharks were raised in seawater tanks under standard conditions of temperature $\left(15-16^{\circ} \mathrm{C}\right), \mathrm{pH}(7.5-8.5)$ and salinity $(35 \mathrm{~g} / \mathrm{L})$ and suitable measures were taken to minimize animal pain and discomfort. All procedures were made according to the guidelines established by the European Communities Council Directive of 22 September 2010 (2010/63/UE) and by Spanish Royal Decree 53/2013 for animal experimentation 
and were approved by the Ethics Committee of the University of Santiago de Compostela.

\section{Tissue processing}

Embryos were deeply anesthetized with $0.5 \%$ tricaine methane sulfonate (MS-222; Sigma, St. Louis, MO, USA) in seawater and separated from the yolk before fixation in $4 \%$ paraformaldehyde (PFA) in elasmobranch's phosphate buffer [EPB: $0.1 \mathrm{M}$ phosphate buffer (PB) containing 1.75\% of urea, $\mathrm{pH}$ 7.4] for 48-72 $\mathrm{h}$ depending on the stage of development. Subsequently, they were rinsed in PB saline (PBS), cryoprotected with $30 \%$ sucrose in PBS, embedded in OCT compound (Tissue Tek, Torrance, CA), and frozen with liquid nitrogen-cooled isopentane. Parallel series of sections (16-18- $\mu \mathrm{m}$ thick) were obtained in transverse planes on a cryostat and mounted on Superfrost Plus (MenzelGlasser, Madison, WI, USA) slides.

\section{BrdU pulse-chase experiments}

BrdU pulse-chase labeling was performed by incubating three catshark embryos at S28, S29 and S30 in $10 \mathrm{mg} / \mathrm{ml}$ of BrdU in oxygenated artificial sea water, after opening the egg shell, for $2 \mathrm{~h} 30 \mathrm{~min}$; embryos were then moved to untreated sea water until they achieve S31, when they were killed by overdose of MS-222 and fixed by immersion in PFA $4 \%$ for $48 \mathrm{~h}$. For detection of BrdU, sections were incubated in $2 \mathrm{~N} \mathrm{HCl}$ for $30 \mathrm{~min}$ at $50{ }^{\circ} \mathrm{C}$ to denature DNA strands. $\mathrm{HCl}$ reaction was stopped by addition of $0.1 \mathrm{M}$ sodium tetraborate and sections were then rinsed in TBS for $10 \mathrm{~min}$ before antibody incubation. Sections were incubated with anti-BrdU antibody at room temperature (RT) overnight and processed for immunofluorescence as described below.

\section{In situ hybridization}

We applied in situ hybridization (ISH) for S. canicula Tbr2/ Eomes, NeuroD1, vGlut1 and Sox2 (ScSox2, ScTbr2, ScNeuroD1, ScvGlut1) genes. These probes were selected from a collection of $S$. canicula embryonic cDNA library (mixed stages S9-S22), submitted to high-throughput EST sequencing (coordinated by Dr. Sylvie Mazan). Sense and antisense digoxigenin-UTP-labeled ScTbr2, ScNeuroD1, ScvGlut1 and ScSox 2 were synthesized directly by transcription in vitro. ISH was performed on cryostat sections of S30, S31 and S32 embryos following standard protocols (Coolen et al. 2009). Briefly, sections were permeabilized with proteinase $\mathrm{K}$, hybridized with sense or antisense probes overnight at $65{ }^{\circ} \mathrm{C}$ and incubated with the alkaline phosphatase-coupled anti-digoxigenin antibody (1:2000, Roche Applied Science, Manheim, Germany) overnight at $4{ }^{\circ} \mathrm{C}$. The color reaction was performed in the presence of BM-Purple (Roche).
Color reaction was stopped by rinsing in PFA $4 \%$ for $45 \mathrm{~min}$. Finally, sections were dehydrated and coverslipped. Control sense probes did not produce any detectable signal.

\section{Immunohistochemistry}

Sections were pre-treated with $0.01 \mathrm{M}$ citrate buffer $\mathrm{pH} 6.0$ for $30 \mathrm{~min}$ at $90{ }^{\circ} \mathrm{C}$ for heat-induced epitope retrieval and allowed to cool for $20 \mathrm{~min}$ at RT. Sections were rinsed in $0.05 \mathrm{M}$ Tris-buffered saline (TBS) pH 7.4 for $5 \mathrm{~min}$ and treated with $10 \% \mathrm{H}_{2} \mathrm{O}_{2}$ in TBS for 30 min at RT to block endogenous peroxidase activity. Sections were rinsed in $0.05 \mathrm{M}$ TBS $\mathrm{pH} 7.4$ for $5 \mathrm{~min}$ and incubated approximately for $15 \mathrm{~h}$ at RT with primary antibodies (see Table 1). Sections were rinsed three times in $0.05 \mathrm{M}$ TBS pH 7.4 for $10 \mathrm{~min}$ each, and incubated in the appropriate HRP-coupled secondary antibody (see Table 1 ) for $1 \mathrm{~h}$ at RT. All dilutions were made with TBS containing 15\% normal goat serum (Millipore, Billerica, MA, USA) 0.2\% Triton X-100 (Sigma) and $2 \%$ bovine serum albumin (BSA, Sigma). All incubations were carried out in a humid chamber. Then, sections were rinsed three times in $0.05 \mathrm{M}$ TBS pH 7.4 for $10 \mathrm{~min}$ each. The immunoreaction was developed with $0.25 \mathrm{mg} /$ $\mathrm{ml}$ diaminobenzidine (DAB) tetrahydrochloride (Sigma) in TBS pH 7.4 and $0.00075 \% \mathrm{H}_{2} \mathrm{O}_{2}$, or with SIGMAFAST TM 3.3-DAB tablets as indicated by the manufacturers. In Pax6 samples, $2.5 \mathrm{mg} / \mathrm{ml}$ nickel ammonium sulfate was added. Finally, the sections were dehydrated, and coverslipped.

\section{Double in situ hybridization- immunohistochemistry}

We applied double in situ hybridization-immunohistochemistry for ScTbr2 and ScNeuroD probes and the Tbr 1 antibody. After colorimetric detection of probes, sections were rinsed three times in $1 \mathrm{M}$ PBS for $10 \mathrm{~min}$ each, rinsed in PFA 4\% for 45 min and immunohistochemistry was performed as described above.

\section{Double immunofluorescence}

For heat-induced epitope retrieval, sections were pre-treated with $0.01 \mathrm{M}$ citrate buffer (pH 6.0) for $30 \mathrm{~min}$ at $90{ }^{\circ} \mathrm{C}$ and allowed to cool for $20 \mathrm{~min}$ at RT. Sections were rinsed in $0.05 \mathrm{M}$ TBS (pH 7.4) for 5 min and incubated approximately for $15 \mathrm{~h}$ at RT with primary antibodies (see Table 1). Sections were rinsed three times in $0.05 \mathrm{M}$ TBS $\mathrm{pH} 7.4$ for $10 \mathrm{~min}$ each, and incubated in the appropriate combination of fluorescent dye-labeled secondary antibodies (see Table 1) for $1 \mathrm{~h}$ at RT. All dilutions were made with TBS containing 15\% normal donkey serum (Millipore, Billerica, MA, USA) $0.2 \%$ Triton X-100 (Sigma) and $2 \%$ bovine serum albumin (BSA, Sigma). All incubations were carried out 
Table 1 Primary and secondary antibodies used

\begin{tabular}{|c|c|c|c|c|c|}
\hline Primary antibody & Source & Working dilution & Secondary antibody & Source & Working dilution \\
\hline Pax6 & $\begin{array}{l}\text { Policlonal rabbit anti-Pax6 } \\
\text { Covance (Cat. No. PRB- } \\
\text { 278P) }\end{array}$ & $1: 300$ & $\begin{array}{l}\text { Goat anti-rabbit HRP } \\
\text { coupled }\end{array}$ & Dako, Glostrup, Denmark & $1: 200$ \\
\hline PCNA & $\begin{array}{l}\text { Monoclonal mouse anti- } \\
\text { PCNA } \\
\text { Sigma (Cat. No. P8825) }\end{array}$ & $1: 500$ & $\begin{array}{l}\text { 488-cojugated donkey anti- } \\
\text { mouse }\end{array}$ & $\begin{array}{l}\text { Alexa Fluor } \\
\text { Molecular Probes, Eugene, } \\
\text { OR }\end{array}$ & $1: 200$ \\
\hline GFAP & $\begin{array}{l}\text { Polyclonal rabbit anti- } \\
\text { GFAP } \\
\text { Dako (Cat. No. Z033429) }\end{array}$ & $1: 500$ & $\begin{array}{l}\text { 546-conjugated donkey } \\
\text { anti-rabbit }\end{array}$ & $\begin{array}{l}\text { Alexa fluor } \\
\text { Molecular Probes, Eugene, } \\
\text { OR }\end{array}$ & $1: 200$ \\
\hline BLBP & $\begin{array}{l}\text { Polyclonal rabbit anti- } \\
\text { BLBP } \\
\text { Millipore (Cat. No. } \\
\text { ABN14) }\end{array}$ & $1: 300$ & $\begin{array}{l}\text { FITC-conjugated goat } \\
\text { anti-rat }\end{array}$ & $\begin{array}{l}\text { ThermoFisher } \\
\text { Cat. No. } 31621\end{array}$ & $1: 100$ \\
\hline Tbr1 & $\begin{array}{l}\text { Policlonal rabbit anti-Tbr1 } \\
\text { Chemicon (Cat. No. } \\
\text { AB9616) } \\
\text { Millipore (Cat. No. } \\
\text { AB10554) }\end{array}$ & $1: 200$ & & & \\
\hline TH & $\begin{array}{l}\text { Monoclonal mouse anti-TH } \\
\text { Millipore (Cat. No. } \\
\text { MAB318) }\end{array}$ & $1: 500$ & & & \\
\hline BrdU & $\begin{array}{l}\text { Policlonal Rat anti-Brdu } \\
\text { Abcam (Cat. No. ab6326) }\end{array}$ & $1: 100$ & & & \\
\hline
\end{tabular}

in a humid chamber. Sections were rinsed three times in $0.05 \mathrm{M}$ TBS pH 7.4 for 10 min each and in distilled water for $30 \mathrm{~min}$. Sections were then allowed to dry for $30 \mathrm{~min}$ at $37{ }^{\circ} \mathrm{C}$, and mounted in MOWIOL 4-88 Reagent (Calbiochem, MerkKGaA, Darmstadt, Germany). Information about the primary and secondary antibodies is included in Table 1.

\section{Control and specificity of antibodies}

The PCNA antibody has been previously used to label progenitor cells in the brain and olfactory system of $S$. canicula (i.e. Quintana-Urzainqui et al. 2014, 2015). In addition, the specificity of the antibody against Pax6 has been tested by pre-absorption test in S. canicula (Ferreiro-Galve et al. 2012). The Tbr1 antibody has been previously used as a marker of pallial glutamatergic neurons in the developing brain of S. canicula (Docampo-Seara et al. 2018a). Antibodies against glial markers GFAP and BLBP and the enzyme TH (marker of dopaminergic cells) have been previously tested by western blot (Carrera et al. 2012; Docampo-Seara et al. 2018b).

\section{Imaging}

Fluorescent sections were photographed with the Leica TCS-SP2 scanning microscope with a combination of blue and green excitation lasers. Confocal images were acquired separately for each laser channel with steps of $2 \mu \mathrm{m}$ along the $\mathrm{z}$-axis, and collapsed images were obtained with the LITE software (Leica). Light field images were obtained with an Olympus BX51 microscope equipped with an Olympus DP71 color digital camera. Images were adjusted for contrast, brightness and intensity using Corel Draw X7.

\section{Results}

In the catshark, the OP emerges as a well-defined protrusion in ventrolateral portions of the telencephalic hemispheres in the transition from S30 to S31 of development (FerreiroGalve et al. 2012). While no cell layering can be appreciated at this stage, incipient glomeruli began to appear, called protoglomeruli, in the distal portion of the OP. At S32, protoglomeruli are more evident and the OB becomes conspicuous and organized in three basic layers, which are, from outside to inside, the olfactory nerve layer, the glomerular layer (protoglomeruli) and the granular layer. Mitral cells, which in the mammalian brain and in other vertebrates constitute a proper layer, do not form a defined layer in the catshark, but rather they are diffusely distributed between the glomerular and granular layers. From S32 onwards, the OB grows and the glomerular layer and granular layer form well-defined layers. For further information about the OB development in the catshark, see Quintana-Urzainqui et al. (2014, 2015). 


\section{Expression of Pax6 and progenitor cell markers in the ventrolateral pallium at stage $\mathbf{3 0}$}

At S30 of development, before the appearance of the OP, the telencephalon is constituted by a large ventricle surrounded by the telencephalic walls. These walls are constituted by a proliferating ventricular zone and an intermediate zone comprised of neuroblasts (Docampo-Seara et al. 2018a). Pallium and subpallium are recognizable because of their differential expression of Pax6 and GAD, respectively (Carrera et al. 2008b; Quintana-Urzainqui et al. 2015; Rodríguez-Moldes et al. 2017), but their main pallial and subpallial subdivisions are not yet established (Fig. 1a). As mitral cell progenitors could be present in the pallial proliferating ventricular zone before the appearance of the OP in a way similar to what happens with mitral cell progenitors in the OB of mammals (Imamura et al. 2011), we have studied the expression pattern of Pax6 (pallial/mitral progenitor marker), ScSox2 (stem cell marker), BLBP-PCNA and GFAP-PCNA (radial glial progenitor cell markers) in the ventricular zone of the ventrolateral portions of the pallium (the presumptive area where the OP is going to emerge) of a S30 embryo (square in Fig. 1a).

Pax6 expression in the pallium was restricted to the pallial ventricular zone in the telencephalon of a S30 embryo, including ventrolateral portions (Fig. 1b). ScSox2 expression was also present in the pallial ventricular zone, where its expression coincides with that of Pax6 (compare Fig. 1b and c). In the same region where numerous Sox2- and Pax6-positive cells were present, numerous BLBP- and GFAP-positive cells were observed; immunoreactivity for both radial glia markers was present in the periphery of the cell bodies and in their basal and apical processes. Double immunofluorescence BLBP/PCNA and GFAP/PCNA showed that all

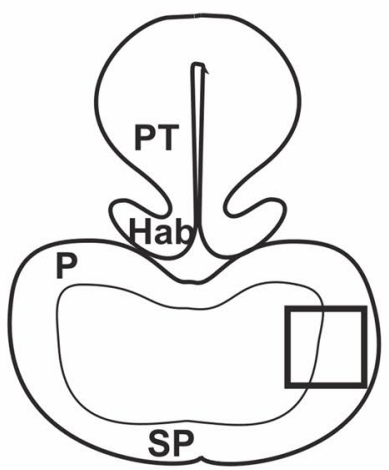

A

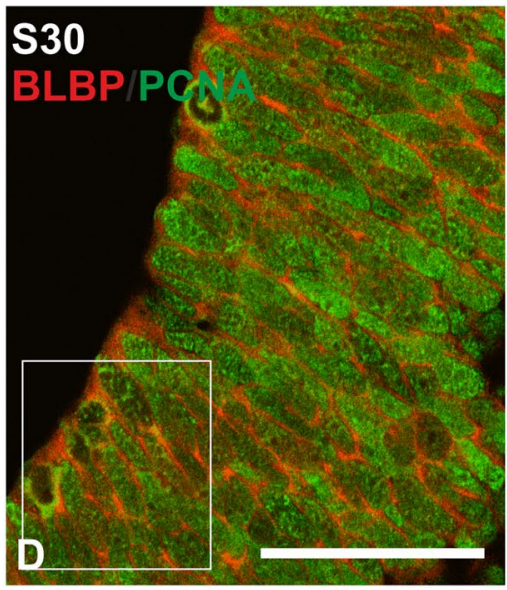

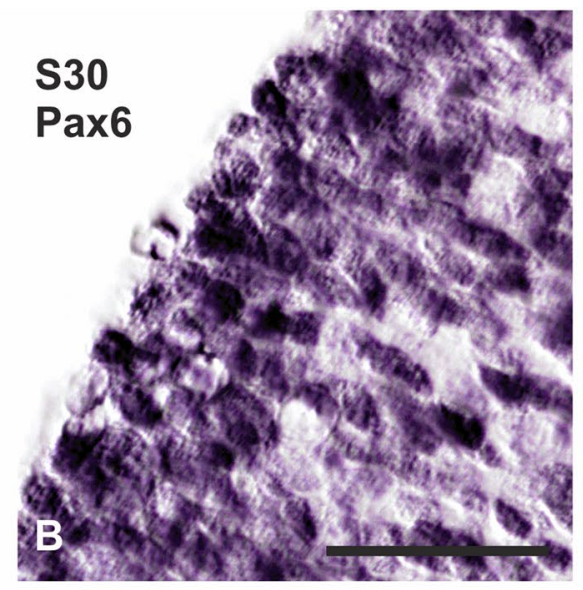
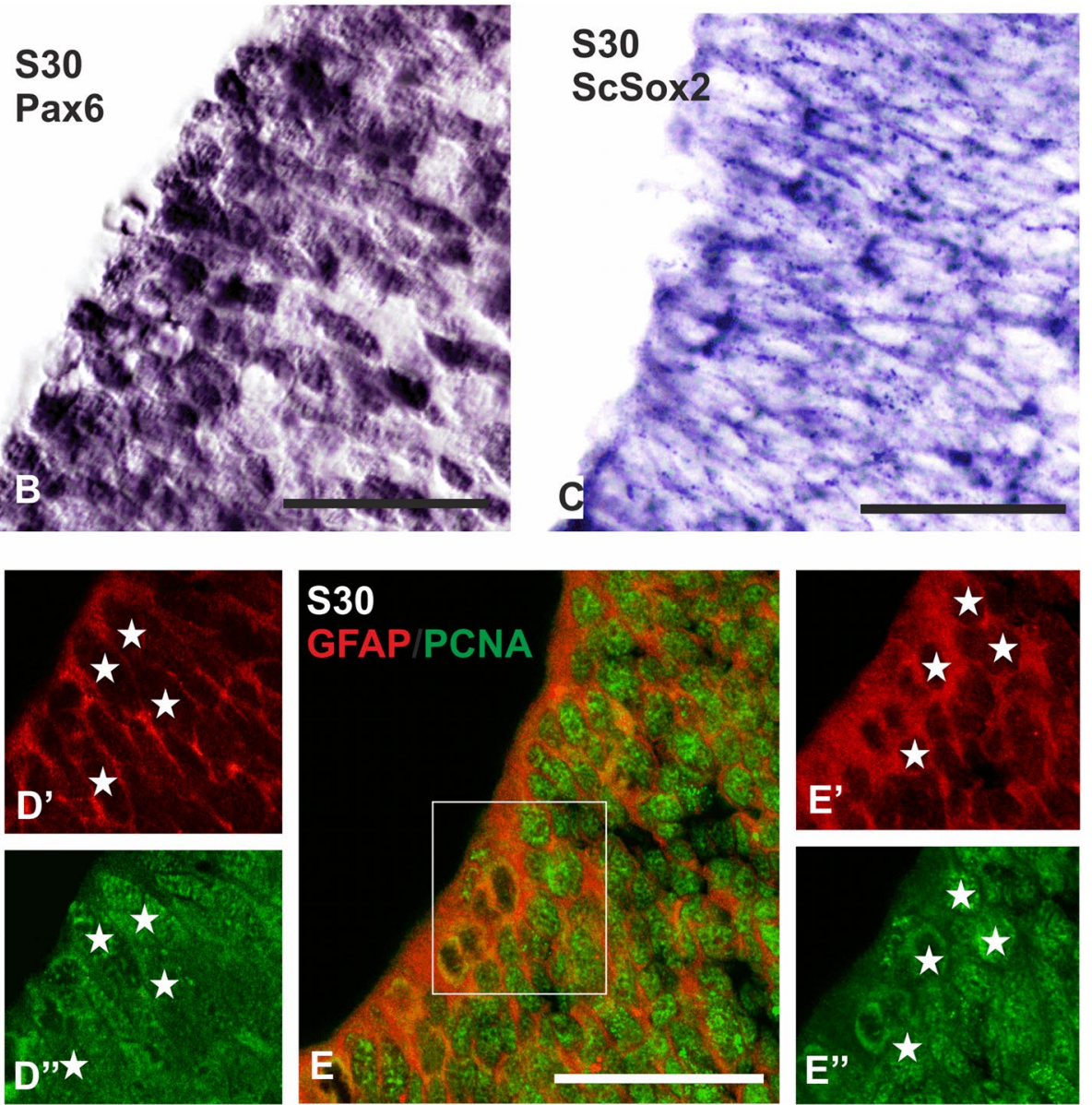

Fig. 1 Transverse sections showing the expression pattern of progenitor markers in the ventricular zone of the telencephalic walls of S30 of development. a Scheme showing the main divisions of the developing brain of a S30 of development. The square represents the portion of the pallium studied at this stage of development. b Photomicrograph at high magnification showing the expression pattern of Pax6 in the ventricular lateral portions of the pallium. Note two dif-

ferent intensities of immunolabeling. c Photomicrograph at high magnification showing the expression pattern of ScSox2. d, d"' Double immunofluorescence BLBP/PCNA in the lateral portions of the pallium showing double-labeled cells (stars). e, e" Double immunofluorescence GFAP/PCNA in the lateral portions of the pallium showing double-labeled cells (stars). Scale bars: $25 \mu \mathrm{m}$. $P$ pallium, Hab habenula, $P T$ pretectum, $S P$ subpallium 
BLBP- and GFAP-expressing cells also expressed PCNA (Fig. 1d, and stars in Fig. 1d', d'; Fig. 1e, and stars in Fig. 1e', e").

\section{Expression pattern of transcription factors (Pax6, ScTbr2, Tbr1 and ScNeuroD) in S31/S32 embryos}

We have studied the main transcription factors involved in mitral cell development (Pax6, Tbr2, NeuroD and Tbr1) at S31 of development (after the OP emerges) and at S32 (when the basic cytoarchitectonic pattern of the OB begins to appear). At S31, numerous Pax6 immunoreactive cells can be observed in the ventricular zone of dorsal and ventrolateral pallial regions (Fig. 2a). Interestingly, a stream
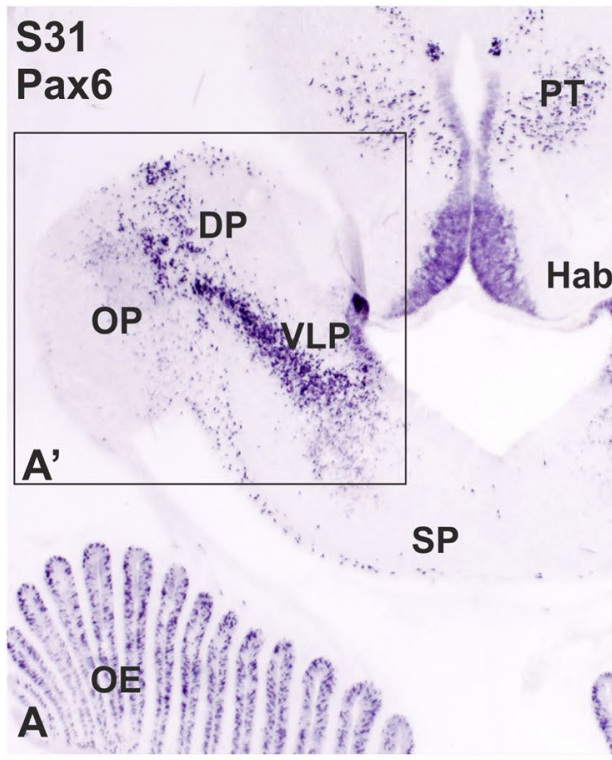

SP
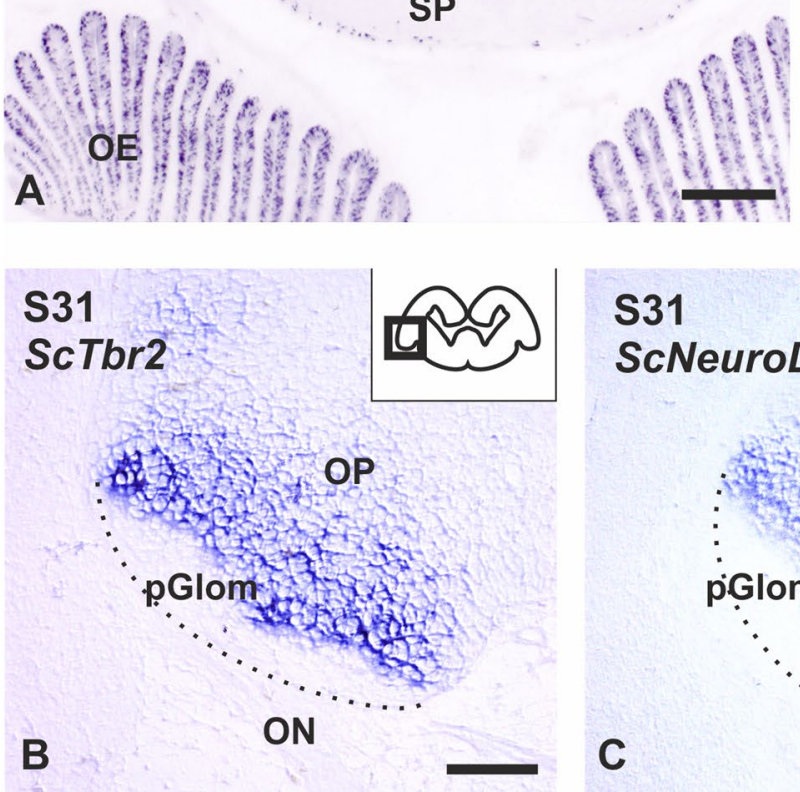

$A^{\prime}$
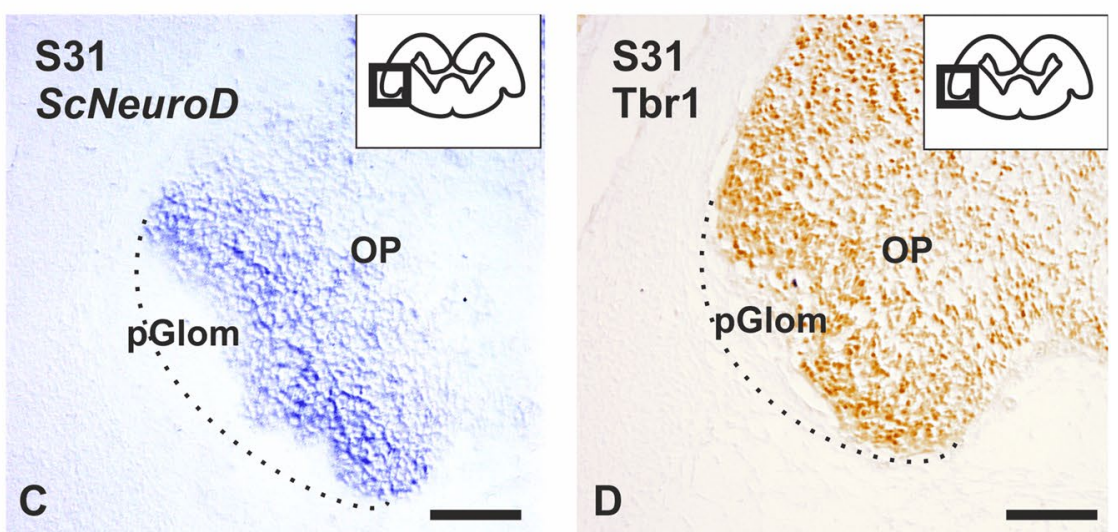

of Pax6-positive cells can be appreciated coursing from the ventricular zone of the ventrolateral pallium to the OP (Fig. 2a'). Curiously, cells that seem to invade the OP show a weaker Pax6 immunoreactivity. Besides, we have also analyzed the expression pattern of ScTbr2, ScNeuroD, and Tbr1. Intense ScTbr2 and ScNeuroD labeling was detected in a cell band adjacent to the most distal region of the OP, where the first protoglomeruli appear, close to the ON entry (Fig. 2b, c), while a faint labeling was observed in proximal regions of the OP. Note that the band of intense labeled cells of both ScTbr2 and ScNeuroD fits with the Pax6-negative territory of the OP (compare Fig. 2a with Fig. 2b and c). In contrast, Tbr1 immunohistochemistry revealed numerous immunoreactive cells in all

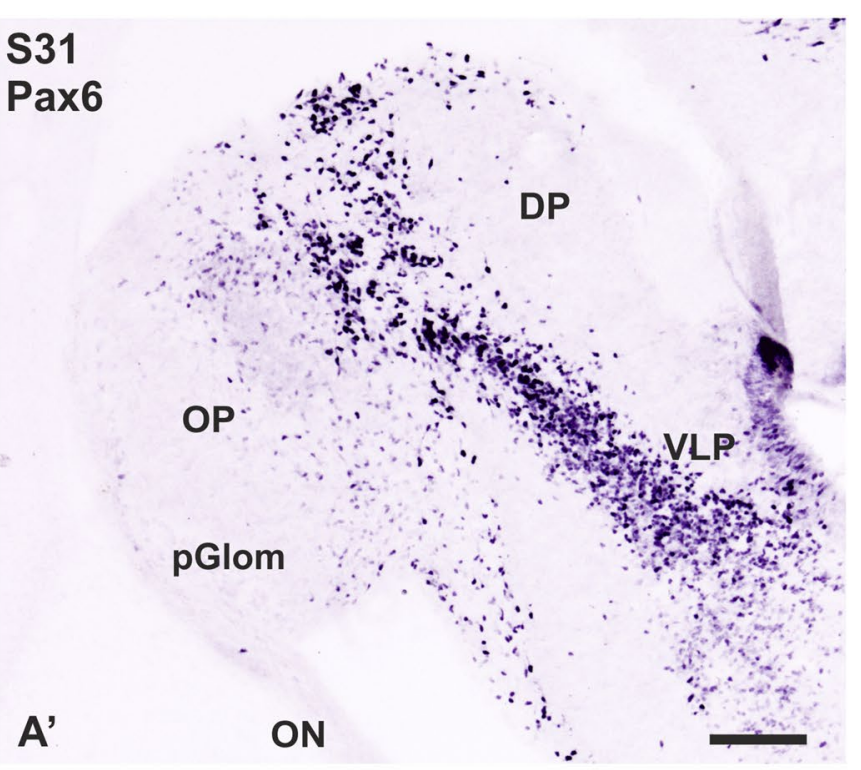

Fig. 2 Transverse sections showing the expression pattern of Pax6 and the neurogenic markers ScTbr2, ScNeuroD and Tbr1 in the OP of S31 of development. a Photomicrograph at low magnification of the telencephalon showing the expression pattern of Pax6 in a S31 of development. a' Detail of the expression pattern of Pax6 showing a stream of Pax6-positive cells coursing from the ventricular zone to the OP. Note that Pax6-positive cells in the OP show low levels of

Pax6. In S31, ScTbr2 (b) and ScNeuroD (c) are expressed as a specific cell band close to the prospective glomerular layer, meanwhile Tbr1 is expressed in all regions of the OP (d). Dotted lines show the limit of the OP. Scale bars: $200 \mu \mathrm{m}$ (a), 100 (a'-d). DP dorsal pallium, $H a b$ habenula, $O E$ olfactory epithelium, $O N$ olfactory nerve, $O P$ olfactory primordium, $P T$ pretectum, $S P$ subpallium, VLP ventrolateral pallium 
regions of the OP, except in the region of protoglomeruli (Fig. 2d).

At S32, the expression pattern of the three transcription factors was restricted to a dense layer of cells in the region adjacent to the protoglomeruli (Fig. 3a-c). As in S31, Tbr1positive cells were also located in proximal regions of the prospective OB (Fig. 3c). Since the expression pattern of ScTbr2 and ScNeuroD was highly coincident but the territory of Tbr1 expression seems to be wider, we performed double in situ hybridization-immunohistochemistry for ScTbr2 and Tbr 1 and for ScNeuroD and Tbr 1 at S32 (Fig. 3d, $\left.\mathrm{e}^{\prime}\right)$. We found that most of the $S c T b r 2$-expressing cells were
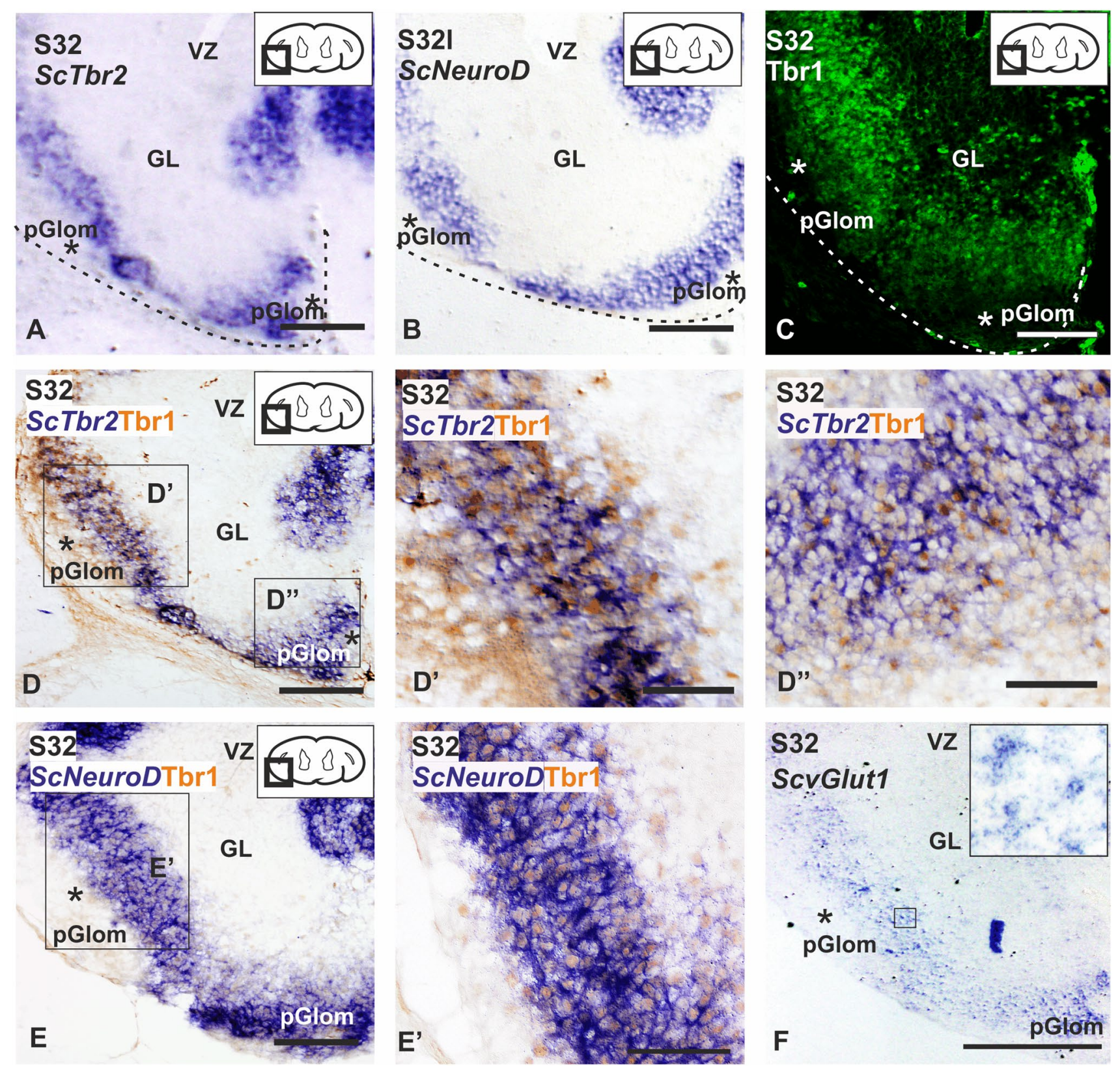

Fig. 3 Transverse sections showing the expression pattern of the neurogenic markers ScTbr2, ScNeuroD, Tbr1 and ScvGlut1 in the OP of S32 of development. In S32 embryos ScTbr2 (a), ScNeuroD (b) and Tbr1 (c) show a similar expression pattern. Note that Tbr1 seems to label a wider territory compared with $S c T b r 2$ and ScNeuroD. Dotted lines shows the limit of the OB. Asterisks show protoglomeruli. Double ISH-IHC between ScTbr2 and Tbr1 (d) in the lateral (d') and ventral (d') portions of the distal OB, showing double-labeled cells.
Note that in the lateral portion Tbr1 immunoreactivity is more abundant (d'), in contrast to the ventral portion, where $S c T b r 2$ is more abundant (d'). e, e' Double ISH-IHC between ScNeuroD and Tbr1 showing an almost total colocalization of both neurogenic markers. $\mathbf{f}$ Photomicrograph showing the expression pattern of $S c v G l u t 1$, coincident with the expression of ScTbr2, ScNeuroD and Tbr1. Scale bars: $100 \mu \mathrm{m}(\mathbf{a}, \mathbf{b}, \mathbf{c}, \mathbf{d}, \mathbf{e}, \mathbf{f}), 50 \mu \mathrm{m}\left(\mathbf{d}^{\prime}, \mathbf{d}^{\prime}, \mathbf{e}^{\prime}\right) . G L$ granular layer, $O P$ olfactory primordium, $p$ Glom protoglomeruli, $V Z$ ventricular zone 
also positive for Tbr1 (Figs. 3d, d'). However, some cells expressed only $S c T b r 2$ or Tbr1. Curiously, most cells that only expressed Tbr1 were located in lateral regions of the distal OB (Fig. 3d'), in contrast to the ventral region, where most of the cells were positive for ScTbr2 only (Fig. 3d"). Concerning ScNeuroD and Tbr1 cell populations, we have observed a high coexpression of both factors in the same cells (Fig. 3e, e') and no differences between the lateral and ventral regions of the $\mathrm{OB}$ were appreciated.

In mammals and other vertebrate groups, these transcription factors are part of a transcriptional code related with the differentiation of pallial glutamatergic neurons (reviewed by Hevner et al. 2006). However, there is no direct evidence about the involvement of these factors in the glutamatergic system in sharks. We have analyzed the expression of the glutamatergic marker ScvGlut1 (vesicular glutamatergic transporter) in $\mathrm{S} 32$ embryos by in situ hybridization. We found numerous $S c v G l u t 1$-positive cells adjacent to the protoglomerular region (Fig. 3f), in the region occupied by ScTbr2/Tbr1/ScNeuroD-expressing cells. In addition, we have performed double immunofluorescence in early S32 embryos for Tbr 1 and the enzyme tyrosine hydroxylase
(TH), which is involved in dopamine synthesis and labels interneurons in the $\mathrm{OB}$ of sharks (Quintana-Urzainqui et al. 2015); Tbr1-expressing cells were observed at this developmental stage; however, TH immunoreactivity was still not observed in the OB (data not shown).

\section{Expression pattern of BrdU in mitral cells presumptive territory at $\mathrm{S} 31$ after pulses at different developmental stages}

As we have determined that cells in the ventrolateral VZ of the pallium typically express mitral cell progenitor markers before the emergence of the OP, we have decided to determine at which point of development, mitral cells are generated. For that, BrdU pulse experiments were performed in catshark embryos at S28, S29 and S30 and embryos were allowed to develop up to $\mathrm{S} 31$. When pulses were performed at S28, most BrdU-positive cells at S31 were concentrated in the portion of the OP that corresponds to the territory labeled by $S c T b r 2$ (Fig. $4 \mathrm{a}$, dotted lines correspond to ScTbr2 territory, see Fig. 2c). On the other hand, when pulses were performed at S29, most BrdU-positive cells at S31 were
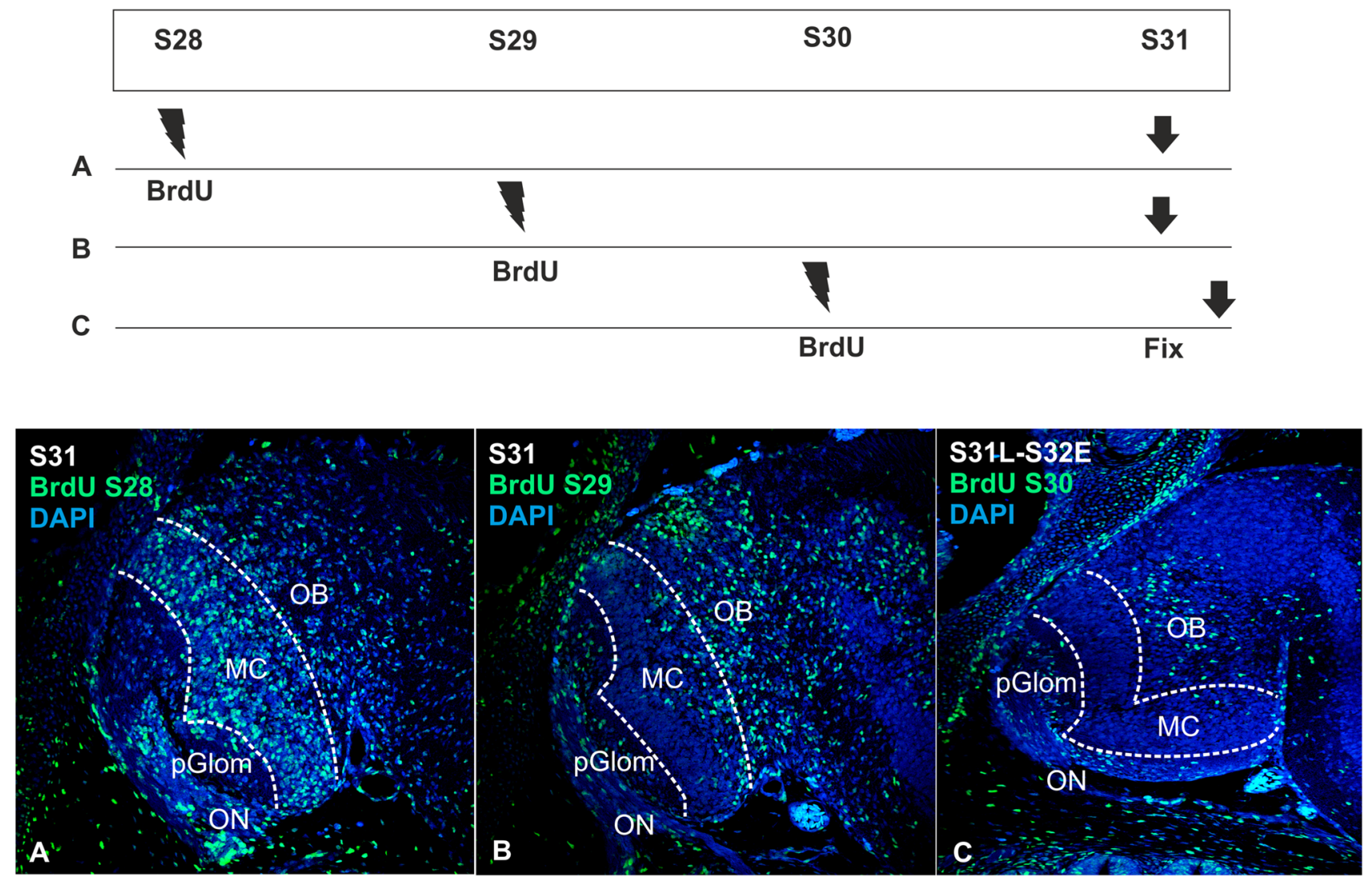

Fig. 4 Scheme and transverse sections showing BrdU immunoreactive cells (green), counterstained with DAPI (blue), in the OB of a S31 embryo after BrdU pulses at S28 (a), S29 (b) and S30 (c). Note that most BrdU-positive cells in mitral cell territory belong to pulses in S28 (a), in contrast to S30 (c), where almost none positive cells can be detected. Dotted lines represent ScTbr2- and ScNeuroD-positive territories, where mitral cells are located. $M C$ mitral cell territory, $O B$ olfactory bulb, $O N$ olfactory nerve, $p G l o m$ protoglomeruli 
concentrated in the prospective granular layer, with a small proportion of positive cells in the olfactory region that would correspond to mitral cells location (Fig. 4b). Finally, when pulses were carried out at S30, barely no BrdU-positive cells were found in the presumptive location of mitral cells at $\mathrm{S} 31$; in contrast, the vast majority of cells were located at the granular portion of the OP (Fig. 4c).

\section{Discussion}

In the present work, we have studied the phenotype of Pax6expressing cells observed in the VZ of the lateroventral pallium of catshark embryos in terms of expression of proliferation and radial glial markers. In addition, we have analyzed the expression of several transcription factors implicated in the differentiation of glutamatergic lineage in the primordial OB of embryos (Pax6, ScTbr2, ScNeuroD, Tbr1). Our results suggest that mitral cells originate from Pax6-expressing radial glial cells in the $\mathrm{VZ}$ of the ventrolateral portion of the pallium that express the same transcription factors described for mitral cell progenitors in mammals (see "Discussion" below).

\section{Pax6-positive cells present in the embryonic telencephalic ventricular zone are proliferating stem cells with molecular hallmarks of radial glia}

Several investigations in mammals have shown that Pax6 is involved in the development of the olfactory placode, the OB and the olfactory cortex (Stoykova and Gruss 1994; Nomura et al. 2007). In amphibians, the expression pattern of Pax6 in the developing OB suggests that this transcription factor also plays a key role in olfactory system development (Franco et al. 2001; Moreno et al. 2008; Joven et al. 2013). In the embryonic OP of mammals, this transcription factor is highly expressed in the ventricular zone (Puelles et al. 2000; Vergaño-Vera et al. 2006). Using molecular markers of radial glia, it was shown that Pax6 is localized in progenitor radial glial cells during mammalian pallial neurogenesis, including the ventricular zone of the embryonic OB (Götz et al. 1998; Imamura and Greer 2013). In addition, mouse neural stem cell lines display many hallmarks of radial glia, like bipolar morphology, including BLBP and Pax6 expression (Conti et al. 2005; Pollard et al. 2006). The level of Pax6 is directly related with neural stem cell self-renewal, proliferation and differentiation (Sansom et al. 2009; Gómez-López et al. 2011).

Previous studies in catshark embryos show that Pax6 is expressed in the developing $\mathrm{OE}$, and immature neurons positive for Pax6 are present along olfactory axons, as it happens in other vertebrates (see Ferreiro-Galve et al. 2012; Quintana-Urzainqui et al. 2014 and references therein). In addition, previous to the emergence of the OP (S30), numerous Pax6 cells were observed in the ventricular zone of the ventrolateral pallium (present results; Ferreiro-Galve et al. 2012). As the molecular phenotype of these cells was not addressed, we have compared the expression pattern of Pax6 with the expression pattern of stem cell marker (ScSox2) and glial markers (GFAP and BLBP) in the embryonic S30 of catshark.

In S30 embryos, numerous Pax6-expressing cells are present in the ventrolateral ventricular zone of the pallium, and differences in the intensity of the Pax6 labeling between positive cells close to the ventricle and cells located far from the ventricle are observed, which are in agreement with the previous studies in the catshark (Ferreiro-Galve et al. 2012). ScSox2-expressing cells are observed at the same location of Pax6-positive cells. Besides, these cells also show immunoreactivity to radial glia markers (GFAP and BLBP) and proliferative activity (PCNA immunoreactivity). Studies with neural stem cell lines indicate that Sox 2 is a marker of stem cells and maintain neural stem cells in a proliferative and undifferentiated state. These studies also show that a complete ablation of Sox 2 expression produces a loss of proliferative capacity; in addition, low levels of Pax6 are necessary to sustain proliferation and bipolar morphology of neural stem cells, while inactivation of Pax6 reduce the proliferative capacity of stem cells (Sakurai and Osumi 2008; Sansom et al. 2009; Gómez-López et al. 2011).

Our results show that Pax6-expressing cells located in the ventricular zone of the ventrolateral pallium express ScSox2, show proliferative capacity (PCNA) and molecular hallmarks of radial glia (GFAP and BLBP expression), as the mammalian neural stem cells present in the pallial ventricular zone.

\section{Neurogenic markers related with the differentiation of glutamatergic cell lineage are expressed in the developing $O B$ of catshark}

In the developing neocortex of mammals, the transcription factor Pax6 is expressed sequentially together with other transcription factors (Tbr2 and Tbr1) in progenitor cells and postmitotic neurons of glutamatergic cell lineage (Englund et al. 2005; Hevner et al. 2006). Interestingly, the transcriptional program that operates in the differentiation of glutamatergic phenotype in the developing neocortex is also necessary for correct morphogenesis of the $\mathrm{OB}$ and generation of mitral cells (Bulfone et al. 1998; Imamura and Greer 2013; Kahoud et al. 2014; Roybon et al. 2015).

In rodents, mitral cells are the first cellular subtype of the OB to be born; these cells are generated around the embryonic day E12 from progenitor cells located in the ventricular zone of the OB (Hinds 1968). Progenitor cells of mitral cells express Pax6 (Winpenny et al. 2011; Imamura and Greer 
2013), and in Pax6 mutant mice mitral cells are misallocated (for review see: Nomura et al. 2007). Tracking experiments in mammals with BrdU labeling show that mitral cells are generated from Pax6-positive radial glial cells and postmitotic mitral cell precursors also express both Tbr 1 and Tbr2 during embryogenesis (Bulfone et al. 1999; Faedo et al. 2002; Imamura and Greer 2013).

Expression of both transcription factors is essential for the generation of mitral cells and its expression occurs in the same developmental period in which Pax6 expression is down-regulated (Imamura and Greer 2013). In Tbr2 mutant mice, the amount of mitral cells is reduced and their organization and projections disturbed, which is similar to what happens in Tbr1 mutant mice (Bulfone et al. 1998, 1999; Imamura and Greer 2013; Kahoud et al. 2014). Moreover, the bHLH transcription factor NeuroD is expressed in the mature glomerular layer, and overexpression of NeuroD leads to the appearance of mature neurons, but knockdown of NeuroD inhibits neuronal differentiation (Boutin et al. 2010). In amphibians, expression of Pax6, Tbr 1 and Tbr2 is detected in the developing OB of embryos or larvae (Brox et al. 2004; Moreno et al. 2003, 2008) and Tbr 1 expression is also present in the OB of zebrafish $48 \mathrm{hpf}$ (Mione et al. 2001).

In the present work, we have detected ScTbr2 and ScNeuroD expression and Tbr1 immunoreactivity in the primordial OB of $\mathrm{S} 31$ of development. Besides, a stream of Pax6-expressing cells can be seen coursing from the VZ of the pallium to the OP of S31 (present results; FerreiroGalve et al. 2012). Interestingly, the expression of Pax6 decreased in ScTbr2- and ScNeuroD-positive territories. In S32 embryos, the expression of ScTbr2, ScNeuroD and Tbr1 becomes restricted to territories adjacent to protoglomeruli; TH immunoreactive granular and periglomerular cells are also observed in the OB in late $\mathrm{S} 32$ embryos (Carrera et al. 2012; Quintana-Urzainqui et al. 2015). We did not find TH immunoreactivity in early S32 embryos indicating that at this developmental period, TH does not colocalize with Tbr1, which is in agreement with previous results in the catshark (Carrera et al. 2012; Quintana-Urzainqui et al. 2015). The expression pattern of neurogenic markers that we found at S32 embryos (present results), seems to be adjacent to the TH-positive cell populations described previously in the catshark, which suggest us that the territories expressing ScTbr2, Tbr1 and ScNeuroD may correspond to the prospective glomerular layer, where mitral cells are intermingled.

In addition, we have shown that both ScTbr2 and ScNeu$r o D$ colocalize with Tbr1, but, as in rodents, it seems that some cells express Tbr 1 or Tbr2 only (Imamura and Greer 2013). In the mammalian developing OB, studies of expression of Tbr 2 and Tbr 1 show that mitral cells express these factors in an overlapping pattern (Imamura and Greer 2013), which is in agreement with our results. On the other hand, in mammals, NeuroD expression pattern also overlapped Tbr2 expression, but not Tbr1 expression, indicating the existence of subsets of mitral cells (Roybon et al. 2015). Besides, recent studies show that maturation of mitral cells depends on their position in the developing OB (Nguyen and Imamura 2019). Some studies in elasmobranchs based on Golgi staining have evidenced the existence of two kind of mitral cells in the OB of the sharks studied (Sphyrna tiburo, Dasyatis sabina and Rhizoprionodon terranovae): mitral cells with dense and tight arborized dendrites and mitral cells with a loose dendrite arborization (Dryer and Graziadei 1993). As far as we know, the existence of more than one type of mitral cells has not been described in $S$. canicula and in the present work, we were not able to define different subsets of mitral cells with the same markers used in mammals. Whether our results are in line with different degrees of maturation deserves further investigations.

In the catshark, the expression pattern of the different neurogenic markers overlapped with that of ScvGlut 1 (present results). In later embryos of rodents, Vglut1 was detected in the mitral cell layer (Ohmomo et al. 2011) and a strong expression of this transporter was also observed in mitral cells of adult reptiles (Sarkar and Atoji 2018).

All these findings together suggest us that Pax6-positive cells (with molecular hallmarks of radial glial cells; see above) that are present in the pallial ventrolateral ventricular zone generate new-born neuroblasts (Pax6 positive) forming a stream of Pax6-positive cells from the ventrolateral pallium to the OP. When these Pax6-expressing cells reach the OP, it seems that they experiment a downregulation of Pax6 expression and begin to upregulate transcription factors related with the specification/differentiation of glutamatergic cells (ScTbr2, ScNeuroD, Tbr1); later in development, when these molecular markers are still expressed, cells begin to express a marker of glutamatergic mitral cells (ScvGlutl) indicating that a maturity stage has been achieved (for a summary see Fig. 5).

In addition, mitral cells in the developing OB of catshark express the same transcription factors related with the differentiation of pallial glutamatergic cell lineage (DocampoSeara et al. 2018a), suggesting that the transcriptional program which rules glutamatergic neurogenesis in different telencephalic areas has been conserved throughout the vertebrate evolution.

\section{The OB of mammals and sharks shares similarities in their developmental timing and molecular programs}

Mitral cells are the first cell type to be born in the mammalian OB. These cells originate from progenitor cells located in the pallial/olfactory ventricular zone before the olfactory axons induce the emergence of the OP (E12) (Gong and 


\section{Mitral cell development in Scyliorhinus canicula}

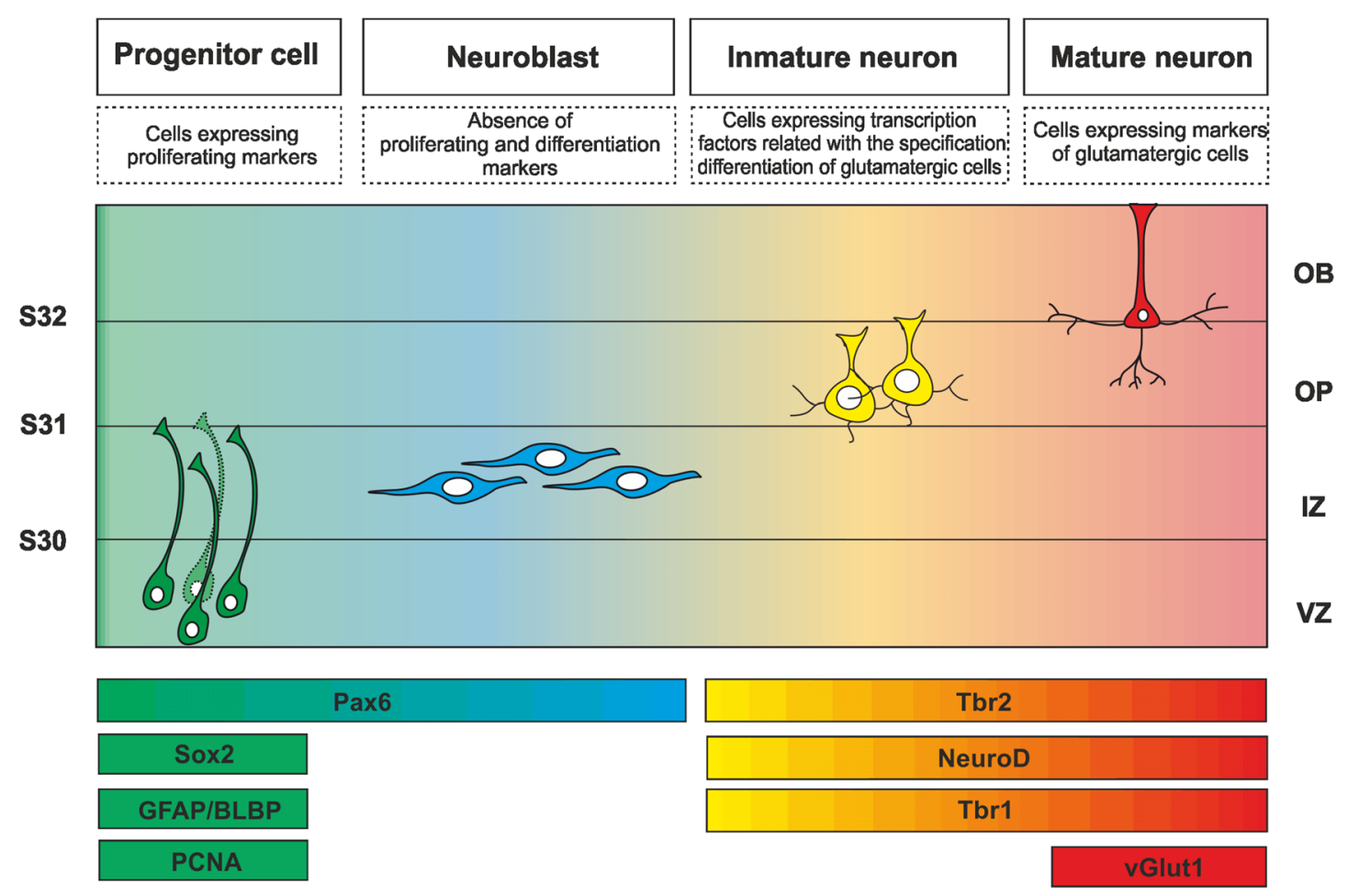

Fig. 5 Scheme summarizing the expression pattern of glutamatergic neurogenic markers implicated in mitral cell development. Cell types and their molecular hallmarks are indicated on the top of the figure. Molecular markers used in the present study are indicated below,

Shipley 1995) and reach the OB following a radial migration process. Their neurogenic timing comprises from E10 to E13, with a neurogenic peak around E11 (Blanchart et al. 2006).

In the catshark, our results indicate that mitral cells are produced in the pallial VZ before the emergence of the OP. In the present work, we have performed BrdU pulse-chase experiments in catshark embryos before the emergence of the OB (pulse in 3 catshark embryos at S28, S29 and S30 and chase at S31, when the OP and markers of mitral cells are present). We found that most mitral cells are generated by progenitor cells that have divided at $\mathrm{S} 28$. However, some of them are also generated at S29. In S30pulse-S31chase BrdU-positive cells in the mitral cell territory are practically inexistent. This suggests that mitral cells are generated between S28 and S29. However, we cannot discard the possibility that some mitral cells could be generated at S30 (or later) and arrive to the $\mathrm{OB}$ later than at S31 of development.

When mitral cells are generated, in contrast to mammals, they seem to migrate tangentially up to $S 31$; later, at S32, a diffuse band of glutamatergic cells is present in the embryonic stages of development are represented as horizontal lines and indicated in the left, and anatomical regions are indicated in the right

primordium $\mathrm{OB}$, which reminds their mature disposition in the adult $\mathrm{OB}$.

On the other hand, in mice, interneurons are generated after the first waves of mitral cells arrive to the OB. Around E13.5, the subpallial lateral ganglionic eminence (LGE), begins to express the distal-less homeobox gene 2 (Dlx2) and, most part of OB interneurons is produced at this embryonic time (Wichterle et al. 2001; Vergaño-Vera et al. 2006; Kohwi et al. 2007). Interneuron production is persistent through the entire life of mammals, but during development, an important neurogenic peak can be detected between E15.5 and 17.5 (Batista-Brito et al. 2008; Lledo et al. 2008). During embryonic development, interneurons follow a tangential migration to the $\mathrm{OB}$ and, once they achieve the $\mathrm{OB}$, they migrate radially and integrate in the $\mathrm{OB}$ circuitry. First interneurons from LGE arrived at the OB around E14.5 (Yoshihara et al. 2005).

As in mammals, in the telencephalon of late embryos of catshark, a subventricular lateral stream of cells positive for $S c D l x 2$ directed towards the olfactory bulb have been observed at S31 (Quintana-Urzainqui et al. 2015). These 
cells originate in the subpallial lateral ganglionic eminence homologue in sharks (LGE-h; Quintana-Urzainqui et al. 2012) from $S 29$ on (Quintana-Urzainqui et al. 2015). After this stream reaches the $\mathrm{OB}$, numerous TH-ir cells are found in the OB from late S32 embryos onwards, which indicate that these cells are the source of the granular and periglomerular cells of the mature OB (Ferreiro-Galve et al. 2012; Carrera et al. 2012; Quintana-Urzainqui et al. 2015). For an integrated view of development in the catshark of both mitral cells and interneurons, see Fig. 6.

Equivalences between different embryonic stages of rodents and sharks have been made according to different developmental key events and three periods have been established (see Table 1 in Rodríguez-Moldes et al. 2017). Stages of development comprised between E10 and 14.5 of mice and S27-31 of catshark are comparable (second period; around 30 days in the catshark), while E14.5-20 of mice corresponds to S32-34 of catshark (third period; up to 100 days in the catshark). According to this, mitral cells are born and arrive to the OP of mice and sharks in the same developmental period. In addition, neurogenesis of dopaminergic neurons (granule and periglomerular cells) in sharks and mice seem to be comparable too. However, in the catshark, we cannot discard the possibility that generation of mitral cells and interneurons could be overlapped in development due to the long protracted embryogenesis of the catshark. An integrative view of both processes shows that the OB of mammals and sharks share similarities not only in their developing molecular programs, but also in the time of generation of projection neurons and interneurons.

\section{The presence of an accessory component in the OB of the catshark: an unsolved question}

Most amphibians, reptiles and mammals possess a dual olfactory system with two separate neural pathways: the main olfactory system and the olfactory accessory system. The accessory olfactory system (or vomeronasal system; VNS) consists in a vomeronasal olfactory epithelium (VNO or Jacobson's organ), an AOB, and the axons of the projecting neurons that reach different regions of the amygdala; from these region projections to hypothalamic regions are

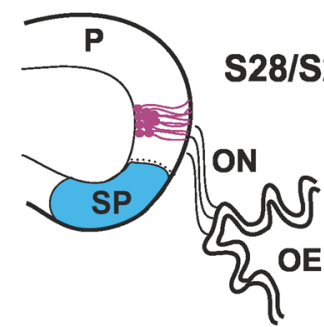

OB primordium formation ac

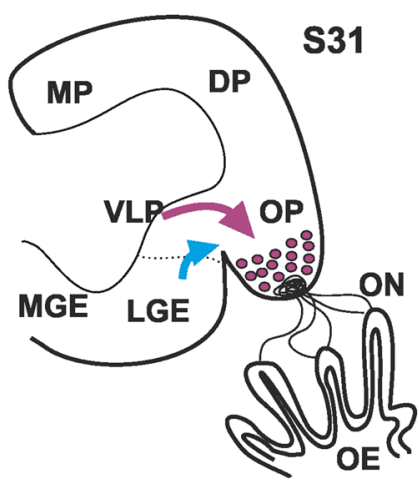

OB

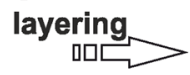

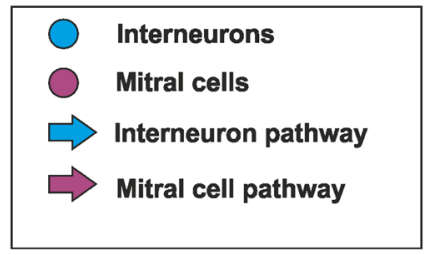

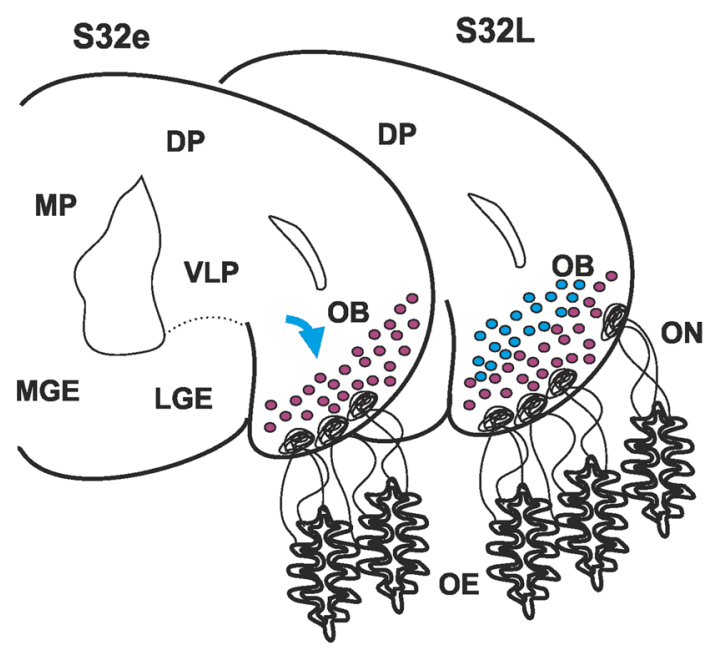

Fig. 6 Scheme summarizing an integrated view of development of both mitral cells (present results) and interneurons in the OB of catshark (data from Quintana-Urzainqui et al. (2015) and Rodríguez-Moldes et al. (2017) 
observed (for review see: González et al. 2010; Maximino et al. 2013).

Although in fish a unique olfactory epithelium is present and an AOB anatomically distinct of the MOB is not recognizable, an accessory olfactory system comparable to the VNS of tetrapods has been described in the lungfish using antibodies against transcription factors and neuronal markers characteristic of distinct portions of the VNS (González et al. 2010). In the catshark, ciliated sensory neurons, the typical cell morphology of the main OE, are lacking, and the main receptor neurons of the olfactory mucosa of Scyliorhinus canicula are the microvillous receptor neurons and crypt neurons, whose projections show a segregated distribution in the OB (Theisen et al. 1986; Ferrando et al. 2009). Genomic studies indicate that VNS-specific genes are present in teleost fish (for review see: Grus and Zhang 2009), cartilaginous fish (Sharma et al. 2019) and sea lamprey (Grus and Zhang 2009). In the catshark, V2R, a component of the vomeronasal signaling pathway, are the predominant chemosensory receptor family, and a small number of genes for chemosensory receptors of the main olfactory system are also present (Sharma et al. 2019).

In rodents, projection neurons of the MOB and anterior $\mathrm{AOB}$ originate from the same pallial ventricular zone. However, projection neurons of the posterior AOB arise from caudal areas located at the diencephalic-telencephalic boundary (Huilgol et al. 2013; Huilgol and Tole 2016). In the present work, we found a migratory stream from the pallial neuroepithelium toward the $\mathrm{OB}$, but we do not have observed any evidence of a migratory stream from the diencephalic-telencephalic boundary towards the OB. Numerous studies in rodents indicate that Pax6 is required for OB mitral cell specification and differentiation in the MOB and anterior AOB (Huilgol and Tole 2016). In addition, Tbr1 is also involved in the specification of the projection neurons of the anterior $\mathrm{AOB}$ but not in the mitral cells of the posterior AOB (Huilgol and Tole 2016). However, in amphibians Tbr 1 is also implicated in the migration of posterior AOB cells (Huilgol et al. 2013).

An important component of the vomeronasal system in rodents is the secondary bulbar projections. In rodents, mitral cells of the AOB project to the medial amygdala and from this region to the hypothalamus (Halpern and Martínez-Marcos 2003). In the lungfish, a region homologue to the medial amygdala of tetrapods expresses the transcription factor orthopedia (Otp) and Islet1 (ISL1), and different neuronal markers such as nitric oxide synthase (nNOS) and substance $\mathrm{P}$ (SP), which is in agreement with results obtained in amphibians (for review see: Maximino et al. 2013; González et al. 2010). In a previous study in the catshark, it was suggested that in S32 embryos, a lateral subpallial region with Pax6-, Dlx2- and GAD-expressing cells represent an amygdala-like structure, and this region in the adult brain shows numerous SP-immunoreactive fibers (Rodríguez-Moldes et al. 1993; Quintana-Urzainqui et al. 2012). In addition, after DiI application to the OB of juvenile of Scyliorhinus canicula, retrogradely labeled cells and fibers were observed in the dorsolateral part of the basal superficial area (a LGE-h derivative in the catshark, Quintana-Urzainqui et al. 2012) and in the lateral hypothalamus (Yáñez et al. 2011). However, further investigations are necessary to elucidate whether the lateral subpallial region in the telencephalon of catshark could be homologue to some amygdaloid territories of tetrapods.

Our results indicate that transcription factors (Pax6 and Tbr1) related with the specification of the MOB and anterior AOB of mammals are present in the catshark. Although we have observed regional differences in the combined expression of Tbr1 and Tbr2 in the OB of catshark, this observation does not allow us to reach any conclusion about the existence of an accessory component in the $\mathrm{OB}$ of the catshark. On the other hand, genomic and other cytological data (for review see: Ferrando and Gallus 2013: Sharma et al. 2019) indicate that the vomeronasal-type receptors component are the predominant in the olfactory epithelium, whereas main olfactory receptors are minority; moreover, ciliated olfactory neurons were not found in the olfactory epithelium of catshark, which suggest that the olfactory mucosa of catshark may be similar to the vomeronasal epithelia of tetrapods. Further, studies of the expression/pattern of transcription factors and neuronal markers related with the specification/ differentiation of different components of the vomeronasal system in the central nervous system are key to elucidate the existence of the brain areas/connections implicated in the processing of vomeronasal-type information in the catshark.

\section{Conclusions}

In the present work, we have carried out a detailed analysis of the transcription factors (Pax6, Tbr2, NeuroD and Tbr1) involved in the glutamatergic neurogenesis during OB development in the catshark. Proliferative Pax6-positive cells with stem cell and radial glial features are present before the emergence of the $\mathrm{OB}$ in the pallial ventricular zone of catshark. Cell tracking analysis using BrdU confirms that progenitors with these characteristics give rise to cells that migrate to the OP and locate in the presumptive territory where glutamatergic/mitral cells should be located. We found that mitral cells in the catshark seem to express the same battery of transcription factors found in mammals, which seem to indicate that the transcription program of glutamatergic cells specification/differentiation has been conserved throughout vertebrates evolution. However, the same factors that in mammals clearly differentiate subsets of 
mitral cells (Tbr2-Tbr1, Tbr2-NeuroD) do not differentiate them in the catshark.

In addition, comparisons between our data and previous studies have evidenced that the origin and expression pattern of transcription factors related with the specification/ differentiation of glutamatergic are common to mammals, evidencing a high conserved pattern of neurogenesis.

Acknowledgements We would like to thank Dr. Ferreiro-Galve for kindly providing anti-Pax6 immunohistochemically stained samples (S31).

Funding This work was supported by the Spanish Ministerio de Economía y Competitividad-FEDER (BFU2014-5863-1P and BFU2017-8986-1P) and CNRS Université Pierre et Marie Curie Grant No. ANR-16-CE13-0013-02.

\section{Compliance with ethical standards}

Conflict of interest The authors declare no conflict of interest.

Ethical approval All procedures conformed to the guidelines established by the European Communities Council Directive of 22 September 2010 (2010/63/UE) and by Spanish Royal Decree 53/2013 for animal experimentation, and were approved by the Ethics Committee of the University of Santiago de Compostela.

Open Access This article is distributed under the terms of the Creative Commons Attribution 4.0 International License (http://creativeco mmons.org/licenses/by/4.0/), which permits unrestricted use, distribution, and reproduction in any medium, provided you give appropriate credit to the original author(s) and the source, provide a link to the Creative Commons license, and indicate if changes were made.

\section{References}

Anadón R, Molist P, Rodríguez-Moldes I, López JM, Quintela I, Cerviño MC, Barja P, González A (2000) Distribution of choline acetyltransferase immunoreactivity in the brain of an elasmobranch, the lesser spotted dogfish (Scyliorhinus canicula). J Comp Neurol 420:139-170

Anadón R, Rodríguez-Moldes I, Adrio F (2013) Glycine-immunoreactive neurons in the brain of a shark (Scyliorhinus canicula L.). J Comp Neurol 521:3057-3082

Ballard WW, Mellinger J, Lechenault H (1993) A series of normal stages for development of Scyliorhinus canicula, the lesser spoted dogfish (Chondrichthyes: Scyliorhinidae). J Exp Zoo 267:318-336

Batista-Brito R, Close J, Machold R, Fishell G (2008) The distinct temporal origins of olfactory bulb interneuron subtypes. J Neurosci 28:3966-3975

Biechl D, Tietje K, Ryu S, Grothe B, Gerlach G, Wullimann MF (2017) Identification of accessory olfactory system and medial amygdala in the zebrafish. Sci Rep 7:44295

Blanchart A, De Carlos JA, López-Mascaraque L (2006) Time frame of mitral cell development in the mice OB. J Comp Neurol 496:529-543

Blanchart A, Martín-López E, De Carlos JA, López-Mascaraque L (2011) Peripheral contributions to OB cell populations (migrations towards the OB). Glia 59:278-292
Boehm U (2006) The vomeronasal system in mice: from the nose to the hypothalamus- and back! Semin Cell Dev Biol 7:471-479

Boutin C, Hardt O, de Chevigny A, Coré N, Goebbels S, Seidenfaden R, Bosio A, Cremer H (2010) NeuroD1 induces terminal neuronal differentiation in olfactory neurogenesis. Proc Natl Acad Sci USA 107:1201-1206

Brox A, Puelles L, Ferreiro B, Medina L (2004) Expression of the genes Emx1, Tbr1, and Eomes (Tbr2) in the telencephalon of Xenopus laevis confirms the existence of a ventral pallial division in all tetrapods. J Comp Neurol 474:562-577

Bulfone A, Smiga SM, Shimamura K, Peterson A, Puelles L, Rubenstein JL (1995) T-brain-1: a homolog of Brachyury whose expression defines molecularly distinct domains within the cerebral cortex. Neuron 15:63-78

Bulfone A, Wang F, Hevner R, Anderson S, Cutforth T, Chen S, Meneses J, Pedersen R, Axel R, Rubenstein JL (1998) An olfactory sensory map develops in the absence of normal projection neurons or GABAergic interneurons. Neuron 21:1273-1282

Bulfone A, Martinez S, Marigo V, Campanella M, Basile A, Quaderi N, Gattuso C, Rubenstein JL, Ballabio A (1999) Expression pattern of the Tbr2 (Eomesodermin) gene during mouse and chick brain development. Mech Dev 84:133-138

Carrera I, Molist P, Anadón R, Rodríguez-Moldes I (2008a) Development of the serotoninergic system in the central nervous system of a shark, the lesser spotted dogfish Scyliorhinus canicula. J Comp Neurol 511:804-831

Carrera I, Ferreiro-Galve S, Sueiro C, Anadón R, Rodríguez-Moldes I (2008b) Tangentially migrating GABAergic cells of subpallial origin invade massively the pallium in developing sharks. Brain Res Bull 75:405-409

Carrera I, Anadón R, Rodríguez-Moldes I (2012) Development of tyrosine hydroxylase-immunoreactive cell populations and fiber pathways in the brain of the dogfish Scyliorhinus canicula: new perspectives on the evolution of the vertebrate catecholaminergic system. J Comp Neurol 520:3574-3603

Chang S, Chung-Davidson YW, Libants SV, Nanlohy KG, Kiupel M, Brown CT, Li W (2013) The sea lamprey has a primordial accessory olfactory system. BMC Evol Biol 13:172

Conti L, Pollard SM, Gorba T, Reitano E, Toselli M, Biella G, Sun Y, Sanzone S, Ying QL, Cattaneo E, Smith A (2005) Nicheindependent symmetrical self-renewal of a mammalian tissue stem cell. PLoS Biol 3:e283

Coolen M, Sauka-Spengler T, Nicolle D, Le-Mentec C, Lallemand Y, Da Silva C, Plouhinec JL, Robert B, Wincker P, Shi DL, Mazan $S$ (2009) Evolution of axis specification mechanisms in jawed vertebrates: insights from a chondrichthyan. PLoS One 2:e374

Curto GG, Nieto-Estévez V, Hurtado-Chong A, Valero J, Gómez C, Alonso JR, Weruaga E, Vicario-Abejón C (2014) Pax6 is essential for the maintenance and multi-lineage differentiation of neural stem cells, and for neuronal incorporation into the adult OB. Stem Cells Dev 23:2813-2830

Dellovade TL, Pfaff DW, Schwanzel-Fukuda M (1998) OB development is altered in small-eye (Sey) mice. J Comp Neurol 402:402-418

Díaz-Guerra E, Pignatelli J, Nieto-Estévez V, Vicario-Abejón C (2013) Transcriptional regulation of OB neurogenesis. Anat Record 296:1364-1382

Docampo-Seara A, Lagadec R, Mazan S, Rodríguez MA, QuintanaUrzainqui I, Candal E (2018a) Study of pallial neurogenesis in shark embryos and the evolutionary origin of the subventricular zone. Brain Struct Funct 223:3593-3612

Docampo-Seara A, Santos-Duran GN, Candal E, Rodríguez MA (2018b) Expression of radial glial markers (GFAP, BLBP and GS) during telencephalic development in the catshark (Scyliorhinus canicula). Brain Struct Funct. https://doi.org/10.1007/ s00429-018-1758-2 
Dryer L, Graziadei PPC (1993) A pilot study on morphological compartmentalization and heterogeneity in the elasmobranch OB. Anat Embryol 188:41-51

Dryer L, Graziadei PPC (1994) Projections of the olfactory bulb in an elasmobranch fish, Sphyrna tiburo: segregation of inputs in the telencephalon. Anat Embryol (Berl) 190:563-572

Dryer L, Graziadei PPC (1996) Synaptology of the olfactory bulb of an elasmobranch fish, Sphyrna tiburo. Anat Embryol (Berl) 193:101-114

Englund C, Flink A, Lau C, Pham D, Daza RA, Bulfone A, Kowalczyk T, Hevner RF (2005) Pax6, Tbr2, and Tbr1 are expressed sequentially by radial glia, intermediate progenitor cells, and postmitotic neurons in developing neocortex. J Neurosci $25: 247-251$

Faedo A, Ficara F, Ghiani M, Aiuti A, Rubenstein JL, Bulfone A (2002) Developmental expression of the T-box transcription factor T-bet/ Tbx21 during mouse embryogenesis. Mech Dev 116:157-160

Ferrando S, Gallus L (2013) Is the olfactory system of cartilaginous fishes a vomeronasal system? Front Neuroanat 17(7):37

Ferrando S, Bottaro M, Gallus L, Girosi L, Vacchi M, Tagliafierro G (2006a) First detection of olfactory marker protein (OMP) immunoreactivity in the olfactory epithelium of a cartilaginous fish. Neurosci Lett 413:173-176

Ferrando S, Bottaro M, Gallus L, Girosi L, Vacchi M, Tagliafierro G (2006b) Observations of crypt neuron-like cells in the olfactory epithelium of a cartilaginous fish. Neurosci Lett 403:280-282

Ferrando S, Gambardella C, Ravera S, Bottero S, Ferrando T, Gallus L, Manno V, Salati AP, Ramoino P, Tagliafierro G (2009) Immunolocalization of G-protein alpha subunits in the olfactory system of the cartilaginous fish Scyliorhinus canicula. Anat Rec (Hoboken) 292:1771-1779

Ferrando S, Gallus L, Gambardella C, Ghigliotti L, Ravera S, Vallarino M, Vacchi M, Tagliafierro G (2010) Cell proliferation and apoptosis in the olfactory epithelium of the shark Scyliorhinus canicula. J Chem Neuroanat 40:293-300

Ferrando S, Gallus L, Gambardella C, Amaroli A, Cutolo A, Masini MA, Vallarino M, Vacchi M (2012) Neuronal nitric oxide synthase (nNOS) immunoreactivity in the olfactory system of a cartilaginous fish. J Chem Neuroanat 43:133-140

Ferreiro-Galve S, Candal E, Rodríguez-Moldes I (2012) Dynamic expression of Pax6 in the shark olfactory system: evidence for the presence of Pax6 cells along the olfactory nerve pathway. J Exp Zool B Mol Dev Evol 318:79-90

Franco MD, Pape MP, Swiergiel JJ, Burd GD (2001) Differential and overlapping expression patterns of X-d1l3 and Pax-6 genes suggest distinct roles in olfactory system development of the African clawed frog Xenopus laevis. J Exp Biol 204(Pt 12):2049-2061

Gillis JA, Shubin NH (2009) The evolution of gnathostome development: insight from chondrichthyan embryology. Genesis 47:825-841

Gómez-López S, Wiskow O, Favaro R, Nicolis SK, Price DJ, Pollard SM, Smith A (2011) Sox 2 and Pax6 maintain the proliferative and developmental potential of gliogenic neural stem cells in vitro. Glia 59:1588-1599

Gong Q, Shipley MT (1995) Evidence that pioneer olfactory axons regulate telencephalon cell cycle kinetics to induce the formation of the OB. Neuron 14:91-101

González A, Morona R, López JM, Moreno N, Northcutt RG (2010) Lungfishes, like tetrapods, possess a vomeronasal system. Front Neuroanat 1:4

Götz M, Stoykova A, Gruss P (1998) Pax6 controls radial glia differentiation in the cerebral cortex. Neuron 21:1031-1044

Grus WE, Zhang J (2009) Origin of the genetic components of the vomeronasal system in the common ancestor of all extant vertebrates. Mol Biol Evol 26:407-419
Halpern M, Martínez-Marcos A (2003) Structure and function of the vomeronasal system: an update. Prog Neurobiol 70:245-318

Hara Y, Yamaguchi K, Onimaru K, Kadota M, Koyanagi M, Keeley SD, Tatsumi K, Tanaka K, Motone F, Kageyama Y, Nozu R, Adachi N, Nishimura O, Nakagawa R, Tanegashima C, Kiyatake I, Matsumoto R, Murakumo K, Nishida K, Terakita A, Kuratani S, Sato K, Hyodo S, Kuraku S (2018) Shark genomes provide insights into elasmobranch evolution and the origin of vertebrates. Nat Ecol Evol 2:1761-1771

Hevner RF, Hodge RD, Daza RA, Englund C (2006) Transcription factors in glutamatergic neurogenesis: conserved programs in neocortex, cerebellum, and adult hippocampus. Neurosci Res $55: 223-233$

Hinds JW (1968) Autoradiographic study of histogenesis in the mouse OB. I. Time of origin of neurons and neuroglia. J Comp Neurol 134:287-304

Huilgol D, Tole S (2016) Cell migration in the developing rodent olfactory system. Cell Mol Life Sci 73:2467-2490

Huilgol D, Udin S, Shimogori T, Saha B, Roy A, Aizawa S, Hevner RF, Meyer G, Ohshima T, Pleasure SJ, Zhao Y, Tole S (2013) Dual origins of the mammalian accessory olfactory bulb revealed by an evolutionarily conserved migratory stream. Nat Neurosci 16:157-160

Imamura F, Greer CA (2013) Pax6 regulates Tbr1 and Tbr2 expressions in olfactory bulb mitral cells. Mol Cell Neuro 54:58-70

Imamura F, Ayoub AE, Rakic P, Greer CA (2011) Timing of neurogenesis is a determinant of olfactory circuitry. Nat Neurosci 14:331-337

Joven A, Morona R, González A, Moreno N (2013) Spatiotemporal patterns of Pax3, Pax6, and Pax7 expression in the developing brain of a urodele amphibian, Pleurodeles waltl. J Comp Neurol 521:3913-3953

Kahoud RJ, Elsen GE, Hevner RF, Hodge RD (2014) Conditional ablation of Tbr2 results in abnormal development of the OBs and subventricular zone-rostral migratory stream. Dev Dyn 243:440-450

Kohwi M, Osumi N, Rubenstein JL, Alvarez-Buylla A (2005) Pax6 is required for making specific subpopulations of granule and periglomerular neurons in the OB. J Neurosci 25:6997-7003

Kohwi M, Petryniak MA, Long JE, Ekker M, Obata K, Yanagawa Y, Rubenstein JL, Alvarez-Buylla A (2007) A subpopulation of olfactory bulb GABAergic interneurons is derived from Emx1and Dlx5/6-expressing progenitors. J Neurosci 27:6878-6891

Lim DA, Alvarez-Buylla A (2016) The adult ventricular-subventricular Zone (V-SVZ) and olfactory bulb (OB) neurogenesis. Cold Spring Harb Perspect Biol 8:a018820

Lledo PM, Merkle FT, Alvarez-Buylla A (2008) Origin and function of olfactory bulb interneuron diversity. Trends Neurosci 31:392-400

Maximino C, Lima MG, Oliveira KR, Batista Ede J, Herculano AM (2013) Limbic associative" and "autonomic" amygdala in teleosts: a review of the evidence. J Chem Neuroanat 48-49:1-13

Méndez-Gómez HR, Vergaño-Vera E, Abad JL, Bulfone A, Moratalla R, de Pablo F, Vicario-Abejón C (2011) The T-box brain 1 (Tbr1) transcription factor inhibits astrocyte formation in the $\mathrm{OB}$ and regulates neural stem cell fate. Mol Cell Neurosci 46:108-121

Mihalas AB, Hevner RF (2017) Control of neuronal development by T-box genes in the brain. Curr Top Dev Biol 122:279-312

Mione M, Shanmugalingam S, Kimelman D, Griffin K (2001) Overlapping expression of zebrafish T-brain-1 and eomesodermin during forebrain development. Mech Dev 100:93-97

Mizuguchi R, Naritsuka H, Mori K, Mao CA, Klein WH, Yoshihara Y (2012) Tbr2 deficiency in mitral and tufted cells disrupts excitatory-inhibitory balance of neural circuitry in the mouse OB. J Neurosci 32:8831-8844

Molist P, Rodriguez-Moldes I, Batten TF, Anadon R (1995) Distribution of calcitonin gene-related peptide-like immunoreactivity in 
the brain of the small-spotted dogfish, Scyliorhinus canicula L. J Comp Neurol 352:335-350

Moreno N, Bachy I, Rétaux S, González A (2003) Pallial origin of mitral cells in the olfactory bulbs of Xenopus. NeuroReport 14:2355-2358

Moreno N, Morona R, López JM, Dominguez L, Muñoz M, González A (2008) Anuran olfactory bulb organization: embryology, neurochemistry and hodology. Brain Res Bull 75:241-245

Mueller T, Wulliman MF (2016) Atlas of early zebrafish brain development. Elsevier ISBN: 978012417269

Nguyen UP, Imamura F (2019) Regional differences in mitral cell development in the mouse olfactory bulb. J Comp Neurol. https ://doi.org/10.1002/cne.24683

Nomura T, Osumi N (2004) Misrouting of mitral cell progenitors in the Pax6/small eye rat telencephalon. Development 131:787-796

Nomura T, Haba H, Osumi N (2007) Role of a transcription factor Pax6 in the developing vertebrate olfactory system. Dev Growth Differ 49:683-690

Ohmomo H, Ehara A, Yoshida S, Shutoh F, Ueda S, Hisano S (2011) Temporally distinct expression of vesicular glutamate transporters 1 and 2 during embryonic development of the rat olfactory system. Neurosci Res 70:376-382

Osorio J, Mueller T, Retaux S, Vernier P, Wullimann MF (2010) Phylotypic expression of the bHLH genes Neurogenin2, Neurod, and Mash1 in the mouse embryonic forebrain. J Comp Neurol 518:851-871

Pollard SM, Conti L, Sun Y, Goffredo D, Smith A (2006) Adherent neural stem (NS) cells from fetal and adult forebrain. Cereb Cortex 16(Suppl 1):i112-i120

Puelles L, Kuwana E, Puelles E, Bulfone A, Shimamura K, Keleher J, Smiga S, Rubenstein JL (2000) Pallial and subpallial derivatives in the embryonic chick and mouse telencephalon, traced by the expression of the genes Dlx-2, Emx-1, Nkx-2.1, Pax-6, and Tbr-1. J Comp Neurol 424:409-438

Quintana-Urzainqui I, Sueiro C, Carrera I, Ferreiro-Galve S, SantosDurán G, Pose-Méndez S, Mazan S, Candal E, Rodríguez-Moldes I (2012) Contributions of developmental studies in the dogfish Scyliorhinus canicula to the brain anatomy of elasmobranchs: insights on the basal ganglia. Brain Behav Evol 80:127-141

Quintana-Urzainqui I, Rodríguez-Moldes I, Candal E (2014) Developmental, tract-tracing and immunohistochemical study of the peripheral olfactory system in a basal vertebrate: insights on Pax6 neurons migrating along the olfactory nerve. Brain Struct Funct 219:85-104

Quintana-Urzainqui I, Rodríguez-Moldes I, Mazan S, Candal E (2015) Tangential migratory pathways of subpallial origin in the embryonic telencephalon of sharks: evolutionary implications. Brain Struct Funct. https://doi.org/10.1007/s00429-014-0834-5

Rodríguez-Moldes I, Manso MJ, Becerra M, Molist P, Anadón R (1993) Distribution of substance P-like ir in the brain of the elasmobranch Scyliorhinus canicula. J Comp Neurol 335:228-244

Rodríguez-Moldes I, Santos-Durán GN, Pose-Méndez S, QuintanaUrzainqui I, Candal E (2017) The Brains of Cartilaginous Fishes. In: Kaas J (ed) Evolution of nervous systems, vol 1, 2nd edn. Elsevier, Oxford, pp 77-97. ISBN 978-0-12-804042-3

Roybon L, Mastracci TL, Li J, Stott SR, Leiter AB, Sussel L, Brundin P, Li JY (2015) The origin, development and molecular diversity of rodent $\mathrm{OB}$ glutamatergic neurons distinguished by expression of transcription factor NeuroD1. PLoS One. https://doi. org/10.1371/journal.pone.0128035

Sakurai K, Osumi N (2008) The neurogenesis-controlling factor, Pax6, inhibits proliferation and promotes maturation in murine astrocytes. J Neurosci 28:4604-4612
Sansom SN, Griffiths DS, Faedo A, Kleinjan DJ, Ruan Y, Smith J, van Heyningen V, Rubenstein JL, Livesey FJ (2009) The level of the transcription factor Pax6 is essential for controlling the balance between neural stem cell self-renewal and neurogenesis. PLoS Genet. https://doi.org/10.1371/journal.pgen.1000511

Sarkar S, Atoji Y (2018) Distribution of vesicular glutamate transporters in the brain of the turtle (Pseudemys scripta elegans). J Comp Neurol 526:1690-1702

Sharma K, Syed AS, Ferrando S, Mazan S, Korsching SI (2019) The chemosensory receptor repertoire of a true shark is dominated by a single olfactory receptor family. Genome Biol Evol 11:398-400

Smeets WJ, Nieuwenhuys R, Roberts BL (1983) The central nervous system of cartilaginous fishes: structure and functional correlations. Springer, Berlin

Stoykova A, Gruss P (1994) Roles of Pax-genes in developing and adult brain as suggested by expression patterns. J Neurosci 14(3 Pt 2):1395-1412

Sueiro C (2003) Estudio immunohistoquímico de los sistemas gabaérgicos del sistema nervioso central de peces elasmobranquios y su relación con sistemas catecolaminérgicos y peptidérgicos. Doctoral Thesis, Universidade de Santiago de Compostela, Spain

Teijido O, Manso MJ, Anadón R (2002) Distribution of thyrotropinreleasing hormone immunoreactivity in the brain of the dogfish Scyliorhinus canicula. J Comp Neurol 54:65-81

Theisen B, Zeiske E, Breuker H (1986) Functional morphology of the olfactory organs in the spiny dogfih (Squalus acanthias L.) and the small-spotted catshark (Scyliorhinus canicula L.). Acta Zool 67:73-86

Treloar HB, Miller AM, Ray A, Greer CA (2010) Development of the olfactory system. In: Menini A (ed) The neurobiology of olfaction. CRC Press/Taylor \& Francis, Boca Raton (FL)

Vergaño-Vera E, Yusta-Boyo MJ, de Castro F, Bernad A, de Pablo F, Vicario-Abejón C (2006) Generation of GABAergic and dopaminergic interneurons from endogenous embryonic olfactory bulb precursor cells. Development 133:4367-4379

Wichterle H, Turnbull DH, Nery S, Fishell G, Alvarez-Buylla A (2001) In utero fate mapping reveals distinct migratory pathways and fates of neurons born in the mammalian basal forebrain. Development 128:3759-3771

Winpenny E, Lebel-Potter M, Fernandez ME, Brill MS, Götz M, Guillemot F, Raineteau O (2011) Sequential generation of OB glutamatergic neurons by Neurog2-expressing precursor cells. Neural Dev 6:12

Yáñez J, Folgueira M, Köhler E, Martínez C, Anadón R (2011) Connections of the terminal nerve and the olfactory system in two galeomorph sharks: an experimental study using a carbocyanine dye. J Comp Neurol 519:3202-3217

Yopak KE, Lisney TJ, Collin SP (2015) Not all sharks are "swimming noses": variation in OB size in cartilaginous fishes. Brain Struct Funct 220:1127-1143

Yoshihara S, Omichi K, Yanazawa M, Kitamura K, Yoshihara Y (2005) Arx homeobox gene is essential for development of mouse olfactory system. Development 132:751-762

Zaccone D, Lo Cascio P, Lauriano R, Pergolizzi S, Sfacteria A, Marino F (2011) Occurrence of neuropeptides and tyrosine hydroxylase in the olfactory epithelium of the lesser-spotted catshark (Scyliorhinus canicula Linnaeus, 1758). Acta Histochem 113:717-722

Publisher's Note Springer Nature remains neutral with regard to jurisdictional claims in published maps and institutional affiliations. 